\title{
The effect of Indian summer monsoon on the seasonal variation of carbon sequestration by a forest ecosystem over North-East India
}

\author{
Pramit Kumar Deb Burman ${ }^{1,2}$ - Dipankar Sarma ${ }^{3}$. Supriyo Chakraborty ${ }^{1,2}$ - Anandakumar Karipot $^{2}$. \\ Atul K. Jain ${ }^{4}(\mathbb{D}$
}

Received: 4 September 2019 / Accepted: 23 December 2019 / Published online: 4 January 2020

(c) Springer Nature Switzerland AG 2020

\begin{abstract}
The Indian summer monsoon is one of the most important yet less understood synoptic processes on the Earth, characterized by an increased amount of rainfall over the entire Indian landmass. The different types of forest ecosystems existing over the Indian region offer a tremendous carbon sequestration potential useful for the global mitigation of climate change as predicted by the modelling studies. The monsoon results in a strong seasonality of the ecosystematmosphere carbon exchange due to the differential availability of two key controlling parameters of photosynthesis namely radiation and water. However, due to the sparsity of surface observations neither the carbon sequestration potential of these ecosystems nor its relation with the monsoon has been analysed comprehensively so far. This paper studies the ecosystem-atmosphere $\mathrm{CO}_{2}$ exchange at a tropical semi-evergreen moist deciduous forest and its relation with the monsoon over north-east India using the eddy covariance and associated meteorological measurements. In 2016, this ecosystem acts as a net source of atmospheric $\mathrm{CO}_{2}$ with net ecosystem exchange of $207.51 \pm 157.37 \mathrm{gC} \mathrm{m}^{-2}$ year $^{-1}$ and gross photosynthesis and ecosystem respiration of $2604.88 \pm 179.43$ and $2812.38 \pm 22.05 \mathrm{gC} \mathrm{m}^{-2}$ year $^{-1}$, respectively. The monsoon clouds are seen to introduce a bimodal pattern in the annual GPP record. The pre-monsoon and winter are the most and least favourable seasons for the photosynthetic $\mathrm{CO}_{2}$ uptake by this forest canopy. Additionally, the rate of increase of photosynthesis with evapotranspiration is maximum and minimum during the pre-monsoon and winter, respectively.
\end{abstract}

Keywords Tropical forest · Net ecosystem exchange $\cdot$ Indian summer monsoon · Eddy covariance $\cdot$ MetFlux India · Carbon sequestration

\section{Introduction}

Terrestrial ecosystems are the largest sink of carbon [54] with a sinking capacity of $3.1 \pm 0.9 \mathrm{GtC}_{\text {year }}{ }^{-1}$ at global scale, whereas several studies have pointed out that some forests act as source of $\mathrm{CO}_{2}$ to the atmosphere [56].
A recent study by Baccini et al. [4] marks the tropical forests as net source of carbon. In contrast, many modelling studies characterized the tropical forests as large sinks of atmospheric carbon $[63,78]$. India is one of the major tropical countries with different tropical forest ecosystems spread across its length and breadth. Although few

Electronic supplementary material The online version of this article (https://doi.org/10.1007/s42452-019-1934-x) contains supplementary material, which is available to authorized users.

Pramit Kumar Deb Burman, pramit.cat@tropmet.res.in | ${ }^{1}$ Centre for Climate Change Research, Indian Institute of Tropical Meteorology, Pune 411008, India. ${ }^{2}$ Department of Atmospheric and Space Sciences, Savitribai Phule Pune University, Pune 411007 , India. ${ }^{3}$ Department of Environmental Sciences, Tezpur University, Tezpur 784028, India. ${ }^{4}$ Department of Atmospheric Sciences, University of Illinois at Urbana-Champaign, Urbana, IL, USA. 
attempts have been made earlier to estimate the carbon sequestration potential of Indian forests by monitoring the ecosystem-atmosphere fluxes of carbon, water and energy in these ecosystems $[45,92,113]$, such efforts are limited in number. Several attempts have also been made to model the productivity of these ecosystems by inverse modelling [84] and ecosystem modelling [6, 31]. However, the south Asian carbon budget by Patra et al. [83] has lots of uncertainties which arise due to the paucity of surface observations from the Indian subcontinent. To account for this problem, several modelling studies have used satellite-observed data for these variables as inputs to the models $[1,114]$, but the satellite-estimated variables fare poorly over the tropical region due to the presence of deep convective clouds causing serious problems in data retrieval. These problems often lead to non-calibration and invalidation of the modelled outputs of water and carbon fluxes over the Indian region.

The Indian summer monsoon (ISM) has a strong effect on the vegetation over the Indian landmass as it brings in ample amount of rainfall. Although there have been several studies across the globe aimed at the understanding the effect of monsoon on the ecosystem functioning [52, $16,121]$, to the best of our knowledge no such comprehensive study exists for the ISM due to the unavailability of surface data.

Apart from the issue of data limitation, it is also important to understand the interrelation of $\mathrm{CO}_{2}$ and water vapour exchanges between the ecosystem and the atmosphere in order to understand the linkages between terrestrial net $\mathrm{CO}_{2}$ flux and ISM. These two exchanges are closely coupled processes as both are controlled through the stomatal opening and closure in the plants [93], mainly controlled by the available light and water, along with other factors, such as meteorology and ecosystem type, and are of utmost importance for upscaling the gross productivity of an ecosystem [53]. While there have been several studies across the globe to quantify these effects on the carbon exchange in different ecosystems [42, 106, 123], such studies over the Indian region are limited [100, 21]. The ISM is the major driver of the seasonality of air temperature and precipitation over the Indian landmass [35, 38]. Hence, it would be important to study the effect of ISM on an Indian ecosystem in this context. Several flux towers have been erected over multiple ecosystems in India for continuous monitoring of the ecosystem-atmosphere fluxes under the aegis of the MetFlux India project initiated by the Ministry of Earth Sciences (MoES), Government of India, and implemented by the Indian Institute of Tropical Meteorology (IITM) [14, 20,34]. We take this opportunity in the present study to use the observations from one of the forest sites of this project to address the issues mentioned above. Specifically, the objectives of the present study are twofold.
First, we want to study the effect of ISM on ecosystematmosphere $\mathrm{CO}_{2}$ exchange. Second, we qualitatively assess the effects of differential seasonal variability of light and water on the $\mathrm{CO}_{2}$ fluxes at this ecosystem.

\section{Data and methods}

\subsection{Flux tower location and instruments}

In 2013, the IITM in collaboration with the Tezpur University installed a 50-m-tall eddy covariance (EC) flux tower over the moist evergreen, semi-deciduous forest, located at the geographic location of $26^{\circ} 34^{\prime} \mathrm{N}, 93^{\circ} 6^{\prime} \mathrm{E}$ (Fig. 1a) within the Kaziranga National Park (abbreviated KNP now onwards) (see the details of the installed instruments and a list of measured variables in Deb Burman et al. [19]) in the state of Assam over north-east India. The KNP site houses one of the densest and undisturbed forest stretches of India. The river Brahmaputra flows through this forested region along with several of its tributaries and distributaries, which is far away from the nearest available human settlement. A significant stretch of this forest is covered by the grassland. A homogeneous and uniform forest cover forms the canopy around the KNP flux tower with an average canopy height of $20 \mathrm{~m}$.

The flora at KNP comprises of eastern wet alluvial grasslands, Assam alluvial plains semi-evergreen forest, tropical moist mixed deciduous forest, Eastern Dillenia swamp forest and wetlands. More details about the floristic composition can be found in Sarma et al. [96]. Major plant species around the canopy include Gmelina arborea Roxb. Mallotus repandas (Willd) Müll. Arg., Tetrameles nudiflora R. Br. etc. The top soil at KNP is mild acidic ( $\mathrm{pH}$ 5.3) and sandy loam type. The Nor'westers are typically observed during the pre-monsoon season at KNP [62], and the forest floor gets flooded during almost every monsoon season [33]. The 30-year surface measurement of precipitation (precip) during 1981-2010 for KNP is recorded at the nearest available meteorological observatory at Tezpur ( $\left.26^{\circ} 37^{\prime} \mathrm{N}, 92^{\circ} 47^{\prime} \mathrm{E}\right)$ by the India Meteorological Department (IMD).

\subsection{Climatic conditions}

The daily averaged values of air temperature $\left(T_{\mathrm{a}}\right)$ and pressure $(P)$ and daily total values of precipitation (precip in $\mathrm{mm}$ ) calculated from the half-hourly records at the KNP site are shown in Fig. 2 of Deb Burman et al. [19]. Based on the variations in $T_{a^{\prime}} \mathrm{P}$, and precip, four distinct seasons are easily identified at KNP. The winter, comprises December, January, and February, is the season with minimum $T_{\text {a }}$ and no precip. The pre-monsoon, comprising March, April, and May, is characterized by an increasing trend in $T_{\mathrm{a}}$. This 


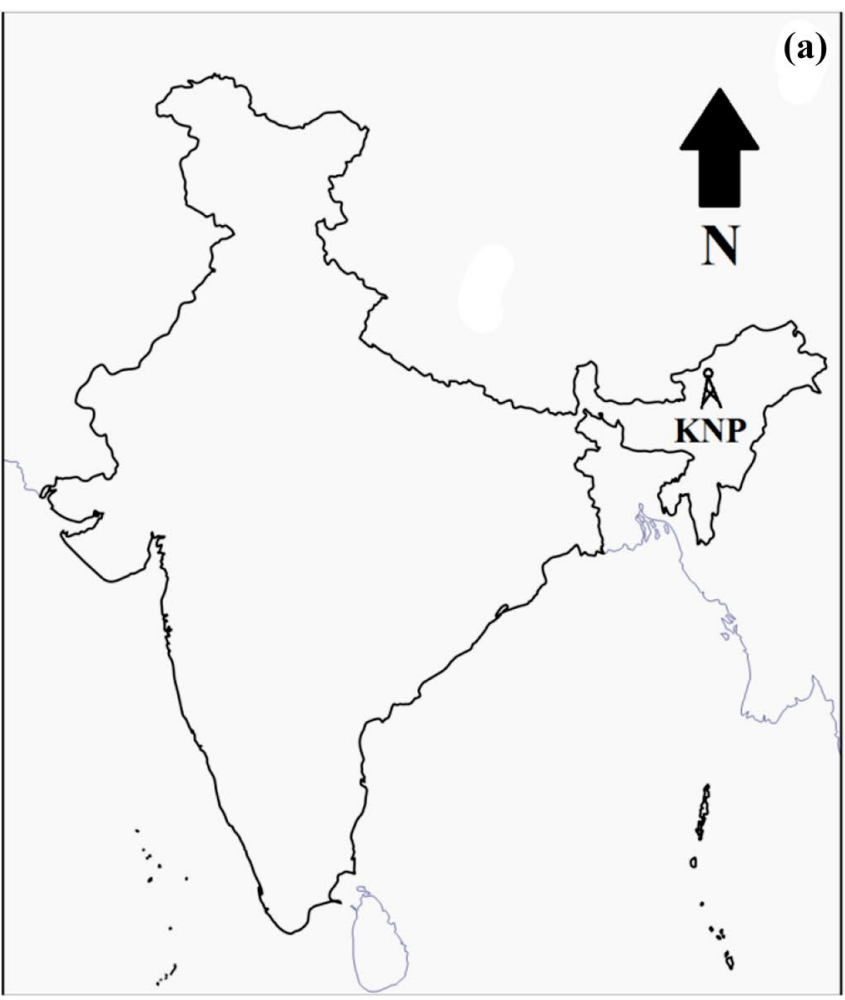

Fig. 1 a Location of the KNP flux tower marked on the map of India. $\mathbf{b}$ Wind rose diagram showing the seasonal variation of wind pattern at KNP. Three concentric circles outward from the centre of the plots show $0-25 \%, 25-50 \%$, and $50-75 \%$ occurrences of the wind, respectively. The different colours show the ranges of horizontal wind speed $\left(v_{h}\right.$ in $\left.\mathrm{m} \mathrm{s}^{-1}\right)$ according to the colour bar. The direction of the stripe represents the direction to which the wind is blowing; $\mathrm{N}=$ north, $\mathrm{NE}=$ north-east, $\mathrm{E}=$ east, $\mathrm{SE}=$ southeast, $\mathrm{S}=$ south, $\mathrm{SW}=$ south-west, $\mathrm{W}=$ west, $\mathrm{NW}=$ north-west, and

intense heating of the land surface results in a surfaceocean temperature anomaly and drives the moistureladen monsoon wind resulting in an increased amount of rainfall, as evident from precip recorded at the KNP site. The monsoon spans over June, July, August, and September and has maximum $T_{\mathrm{a}}$ and maximum precip. The postmonsoon, the shortest season spanning from October to November, records a decreasing trend in $T_{a}$, and almost no precip. Climatological existence of such classification of seasons is well established in the available literature [41, $81,112]$.

\subsection{Flux calculation and gap filling}

We have used the 1-year-long surface observation from KNP during 2016 in our analysis, the details about which can be found in Deb Burman et al. [19]. The variables used in the present study are enlisted in Table 1 of supplementary material 1 and provided as supplementary

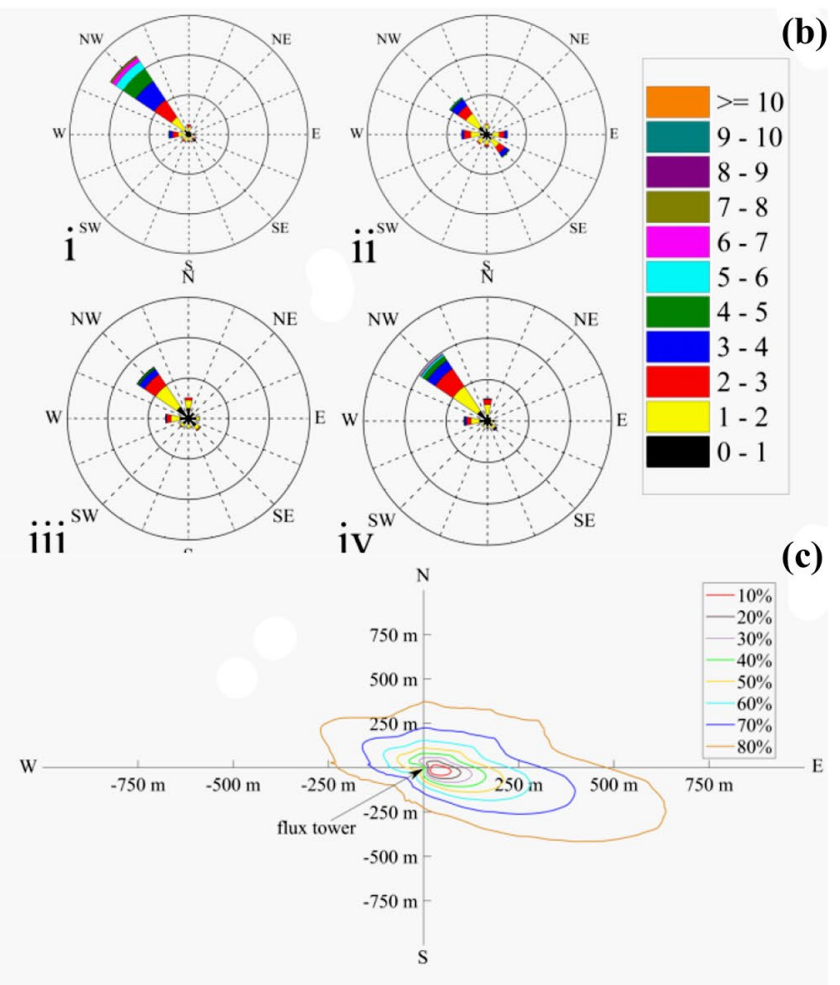

$\mathrm{N}=$ north. In this work, increments of $2 \mathrm{~m} \mathrm{~s}^{-1}$ and $22.5^{\circ}$ have been used in speed and direction of the wind, respectively. Different seasons are marked as (i) pre-monsoon, (ii) monsoon, (iii) post-monsoon and (iv) winter. Data are from the WXT520 multi-component weather sensor at $37 \mathrm{~m}$ on the KNP flux tower. c 2D flux footprint climatology for the KNP flux tower for 2016 calculated following [50]. Footprint contour lines are shown from 10 to $80 \%$ in steps of $10 \%$

material 2. The fluxes of $\mathrm{CO}_{2}$ and water vapour were calculated from the EC data following the Reynolds averaging method [29]. A set of rigorous quality control measures were applied as described by Webb et al. [116], Kaimal and Finnigan [46], Moncrieff et al. [69, 70], Vickers and Mahrt [111], Foken et al. [30], Nakai et al. [73], Papale et al. [80] and Burba and Anderson [12]. The threshold for $\mathrm{u}^{*}$-filtering has been kept at $0.15 \mathrm{~m} \mathrm{~s}^{-1}$. All these applied procedures are described in detail in Deb Burman et al. [19].

Gaps in the measured flux are more or less uniformly distributed throughout the measurement period. Overall, nighttime gaps are more prominent in post-monsoon and winter, and daytime gaps occur mostly during premonsoon and monsoon. Gaps in the data are filled using the marginal distribution sampling (MDS) $[25,117]$, and after gap filling, approximately $40 \%$ of the original measurements are retained. 


\subsection{Flux partitioning}

The $\mathrm{CO}_{2}$ flux measured by EC represents the net exchange of carbon between the ecosystem and the atmosphere, Net Ecosystem Exchange (NEE), defined as NEE $=-$ Gross Primary Productivity (GPP) + Total Ecosystem Respiration (TER). According to the sign convention followed here, the negative and positive values of NEE represent the uptake and release of $\mathrm{CO}_{2}$ by the ecosystem. Here TER is the sum of autotrophic and heterotrophic respirations $[26,37]$.

In the present work, annual record of NEE during 2016 at a half-hourly time resolution has been used to estimate GPP following Reichstein et al. [90]. In this method, the nighttime dependence of TER on air temperature $\left(T_{\mathrm{a}}\right.$ in $\left.{ }^{\circ} \mathrm{C}\right)$ is calculated using the following exponential regression model by Lloyd and Taylor [59].

$\mathrm{TER}=R_{\text {ref }} \exp \left[E_{0}\left(1 /\left(T_{\text {ref }}-T_{0}\right)-1 /\left(T-T_{0}\right)\right)\right]$.

The equation parameters have been defined in Table 1. Finally, TER and NEE are used to calculate GPP. We have used the R-package REddyProc [117] for these calculations.

A certain additional amount of $\mathrm{CO}_{2}$ is stored in the canopy not participating in the canopy-atmosphere exchange process and hence left unmeasured by the EC system [25, 95]. We have neglected this storage term, because, averaged over a complete diurnal cycle, this term becomes negligible compared to the NEE [28]. Additionally, the loss/ gain of $\mathrm{CO}_{2}$ flux due to measurement error and advection is considered to be minimal [36] and also neglected.

Four quality flags (QF) ranging from 0 to 3 are assigned to the gap-filled NEE record to denote its quality. The NEE values having QF 0 correspond to the actually measured values and hence have maximum confidence. Higher QFs denote gap-filled NEE records with decreasing confidence. In order to account for the errors in NEE due to gap filling, two daily averages of NEE are calculated separately from the actually measured and gap-filled NEE values and NEE values with QF in $[0,1][65]$. The annual root mean square (RMS) value of the differences between these two estimates is used as the measure of uncertainty in the annual NEE [71]. Similar QFs are assigned to TER and GPP to denote the values computed from actually measured NEE (i.e. $Q F=0$ ) and the values computed from gap-filled NEE (i.e. QF $=[1,3]$ ) and hence, the measures of uncertainty in TER and GPP are calculated in similar way as described above for NEE.

\subsection{Flux footprint modelling}

The flux footprint of the KNP flux tower, defined as the physical area contributing maximum to the measured flux [3], was modelled using the 2D climatological flux footprint prediction (FFP) model [50] based on the Lagrangian stochastic particle dispersion model LPDM-B [51]. Boundary layer height is an input parameter in this model. It was not directly measured at the site and hence has been calculated according to the available literature $[7,23,74,86$, $98,105]$. More details regarding these calculations can be found in the supplementary material section S2.

\subsection{Light response curve}

The light response curve (LRC), a relationship between the NEE and PPFD [55], has been used to describe the effect of radiation on the carbon uptake mechanism in different seasons. It is represented by the Michaelis-Menten relationship [40, 44, 93]:

$\mathrm{NEE}=\frac{\alpha \cdot \mathrm{PPFD} \cdot \mathrm{NEE}_{\mathrm{sat}}}{\alpha \cdot \mathrm{PPFD}+\mathrm{NEE}_{\mathrm{sat}}}+\mathrm{TER}$.

Additional biophysical variables, estimated from the LRC, are used in our study to understand the ecosystem

Table 1 Parameters of Eqs. 1 (Lloyd-Taylor equation), 2 (Michaelis-Menten equation) and 3

\begin{tabular}{lllll}
\hline Symbol & Definition & Value & Unit & References \\
\hline$T_{0}$ & Regression parameter & -46.02 & ${ }^{\circ} \mathrm{C}$ & Wutzler et al. [117] \\
$T_{\text {ref }}$ & Reference temperature & 15 & ${ }^{\circ} \mathrm{C}$ & Wutzler et al. [117] \\
$E_{0}$ & Activation energy & Varies & $\mathrm{J}$ & Wutzler et al. [117] \\
$R_{\text {ref }}$ & Regression parameter & Varies & $\mathrm{J}$ & Wutzler et al. [117] \\
$a$ & Apparent quantum yield; initial slope of Eq. 2 & Varies & $\mu \mathrm{mol} \mathrm{CO}_{2} \mu \mathrm{mol}^{-1}$ photons & Pingintha et al. [85] \\
$\mathrm{NEE}$ & NEE at infinite light level & Varies & $\mu \mathrm{mol} \mathrm{m}^{-2} \mathrm{~s}^{-1}$ & Pingintha et al. [85] \\
$F_{\mathrm{m}}$ & Photosynthetic capacity; NEE at maximum PPFD & Varies & $\mu \mathrm{mol} \mathrm{m}^{-2} \mathrm{~s}^{-1}$ & Pingintha et al. [85] \\
$\mathrm{LCP}$ & Light compensation point; value of PPFD at zero NEE & Varies & $\mu \mathrm{mol} \mathrm{m}^{-2} \mathrm{~s}^{-1}$ & Kim and Verma [48] \\
$R_{\mathrm{d}}$ & Dark respiration rate; value of NEE at zero PPFD & Varies & $\mu \mathrm{mol} \mathrm{m}^{-2} \mathrm{~s}^{-1}$ & Ruimy et al. [93] \\
$\mathrm{GPP}_{\mathrm{dd}}$ & Daily total GPP & Varies & $\mathrm{gC} \mathrm{m}^{-2} \mathrm{day}^{-1}$ & Farquhar and Richards [27] \\
$\mathrm{ET}_{\mathrm{dd}}$ & Daily total ET & Varies & $\mathrm{kg} \mathrm{H}_{2} \mathrm{O} \mathrm{m}^{-2} \mathrm{day}^{-1}$ & Farquhar and Richards [27] \\
\hline
\end{tabular}

SN Applied Sciences 
response to the available radiation. These variables and all the equation parameters are defined in Table 1.

\subsection{Water use efficiency}

Water use efficiency (WUE), defined here as the ratio between GPP and evapotranspiration (ET) of an ecosystem [124], is used to qualitatively asses the linkage between carbon and water cycles at the ecosystem level. The more is the value of WUE, the less is the required amount of radiation per unit amount of carbon fixation.

Following Farquhar and Richards [27], we calculate daily WUE, defined as,

$W U E_{d d}=\frac{G P P_{d d}}{E T_{d d}}$

The definitions of all the equation parameters are provided in Table 1. We have calculated $W_{U} E_{d d}$ for different seasons.

\section{Results}

\subsection{Site meteorological conditions}

Figure $1 \mathrm{~b}$ shows the wind rose plots at KNP during the different seasons in 2016 . Wind was predominantly southeasterly with a prominent seasonal variation in speed. Strongest wind is observed during pre-monsoon, with maximum wind speed of 9-10 $\mathrm{m} \mathrm{s}^{-1}$. A homogeneous and uniform forest cover extending till $2 \mathrm{~km}$ in the north, $1.5 \mathrm{~km}$ in the east, $2 \mathrm{~km}$ in the south, and $1 \mathrm{~km}$ in the west forms the canopy around the KNP flux tower with an average canopy height of $20 \mathrm{~m}$. As seen from Fig. 1c, the area pertaining to $80 \%$ of the flux contributions extends approximately up to $375 \mathrm{~m}$ in the north, $625 \mathrm{~m}$ in the east, $400 \mathrm{~m}$ in the south and $300 \mathrm{~m}$ in the west. Clearly, this footprint (Fig. 1c) is stretched along northwest to southeasterly direction, which is coherent with the mean annual southeasterly wind (Fig. 1a). Hence the flux footprint area is confined well within the 'canopy' making the site homogeneous.

The monthly cumulative precipitation (precip $\mathrm{mm}_{\mathrm{m}}$ in $\mathrm{mm}$ ) at KNP during 2016 is compared against its latest 30-year mean in Fig. 2a. Based on this long-term pattern, the KNP ecosystem receives annually maximum rainfall in July, approximately equal to $300 \mathrm{~mm}$. The annual patterns of daily total incoming solar radiation $\left(R_{\mathrm{g}}\right.$ in $\mathrm{MJ} \mathrm{m}^{-2}$ day $\left.^{-1}\right)$ and PPFD ${ }_{\mathrm{dd}}\left(\mathrm{mol} \mathrm{m}^{-2}\right.$ day $\left.^{-1}\right)$ show gradually increasing and decreasing trends of radiation in pre-monsoon and post-monsoon, with least amount of radiation in winter and a sharp drop in the middle of monsoon (Fig. 2b). This
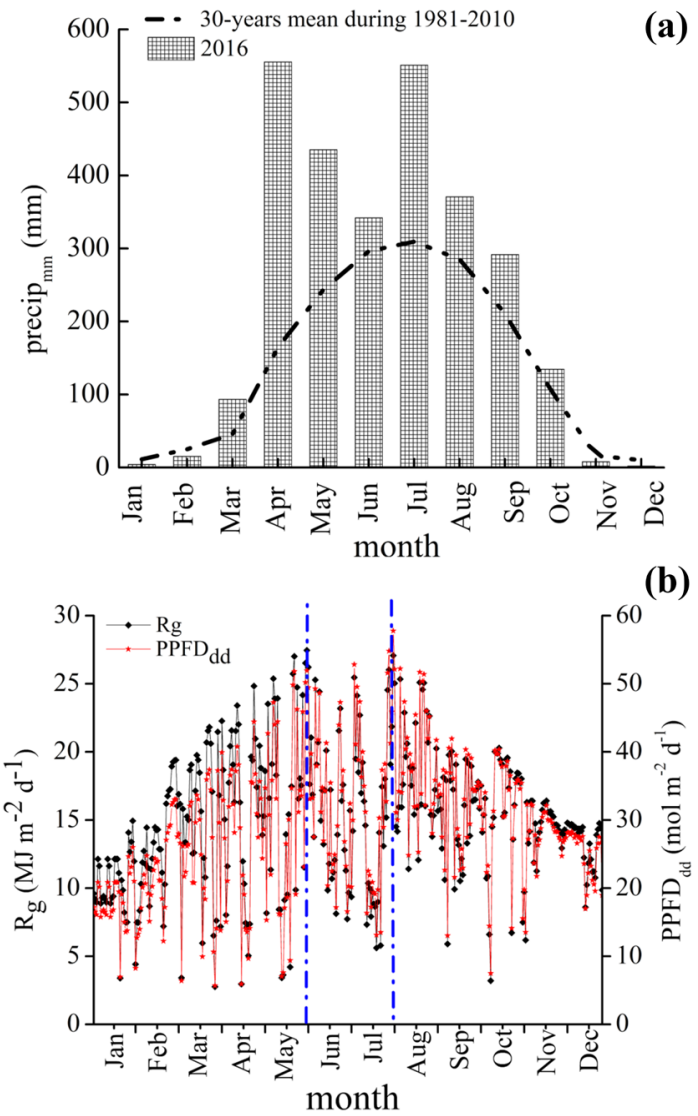

Fig. 2 Annual variations of a monthly total precipitation ( precip $_{\mathrm{mm}}$ ) in 2016 and its 30-year mean during 1981-2010 and b daily total incoming shortwave radiation $\left(R_{\mathrm{g}}\right)$ and daily total photosynthetic photon flux density $\left(\right.$ PPFD $_{\text {dd }}$ ) at KNP during 2016. The rainfall data in 2016 are measured at 4, 7, 20, and $37 \mathrm{~m}$ on the tower and averaged. The rainfall data during 1981-2010 are measured and provided by IMD. The radiation data are measured at $24 \mathrm{~m}$ on the flux tower. $\mathbf{a}$ and $\mathbf{b}$ are in monthly and daily time resolutions, respectively

aspect of available radiation at KNP plays a crucial role in the ecosystem-atmosphere carbon exchange as we are going to explore later in this article.

\subsection{Annual carbon budget}

The yearlong record of daily NEE $\left(\mathrm{NEE}_{\mathrm{dd}}\right.$ in $\mathrm{gC} \mathrm{m}^{-2}$ day $\left.^{-1}\right)$ during 2016 (Fig. 3) shows a prominent seasonal variation. The $\mathrm{NEE}_{\mathrm{dd}}$ is positive during most of the winter as $T_{\mathrm{a}}$ [19]

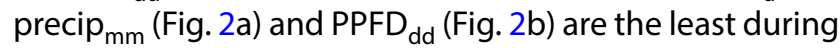
this time. In addition, the maintenance respiration of the ecosystem continues. During winter months, a cold and dry environment with low $R_{\mathrm{g}}$ and consistent TER $\mathrm{R}_{\mathrm{dd}}$ results in a lower gross uptake in this season compared to the other seasons. These are visible in the daily total values of GPP and TER (GPP dd and TER $R_{d d}$, respectively, in $\mathrm{gC} \mathrm{m}^{-2}$ day $^{-1}$ ), plotted in Fig. 4. This hindrance of photosynthetic 


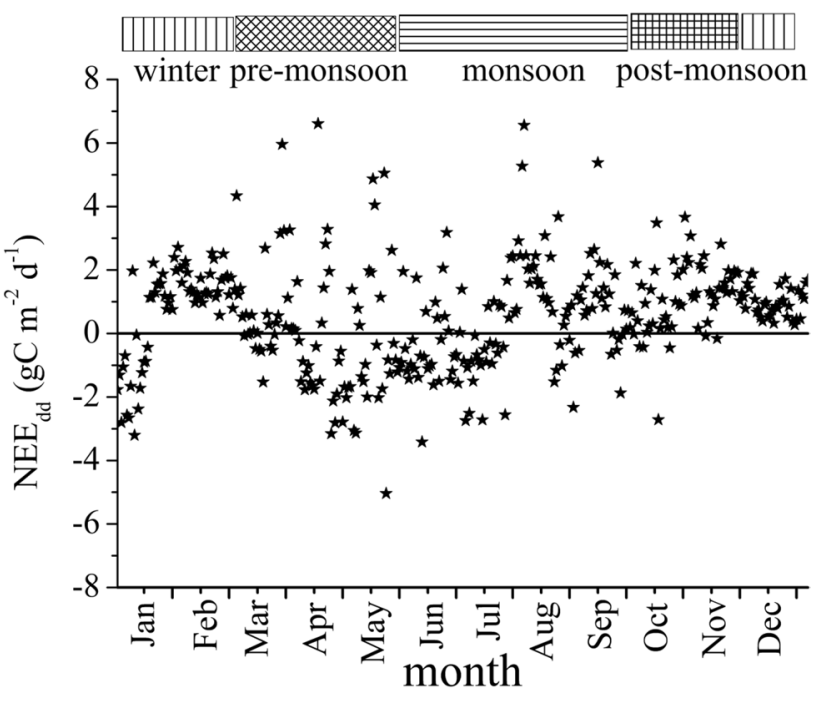

Fig. 3 Annual variations of daily net ecosystem exchange $\left(\mathrm{NEE}_{\mathrm{dd}}\right)$ at KNP during 2016. Different seasons are marked at the top of the figure using different shading schemes. Data are from the eddy covariance (EC) system at $37 \mathrm{~m}$ on the flux tower. This plot is in daily time resolution

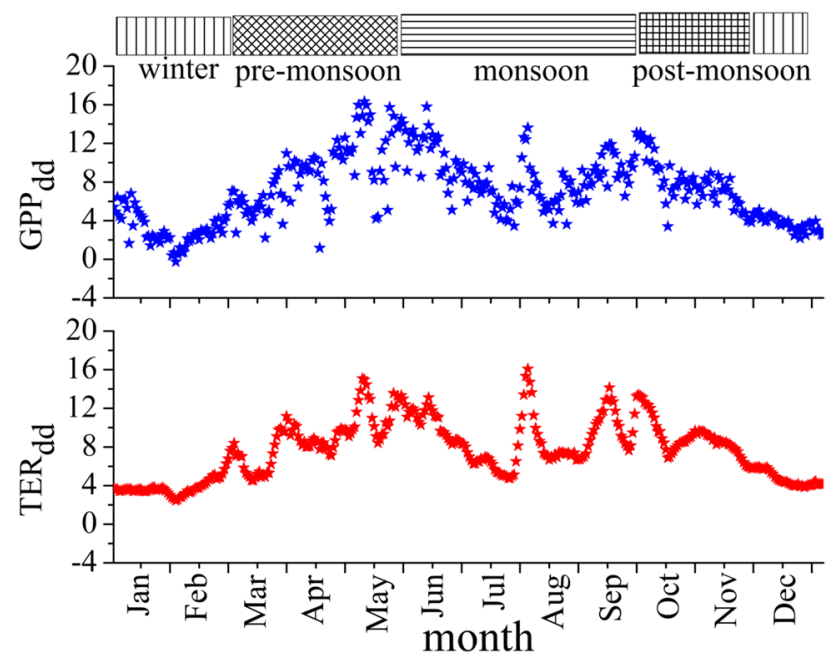

Fig. 4 Annual variations of daily gross primary productivity $\left(\mathrm{GPP}_{\mathrm{dd}}\right)$ and daily ecosystem respiration (TER dd $)$ at KNP during 2016. Different seasons are marked at the top of the figure using different shading schemes. Data are from the eddy covariance (EC) system at $37 \mathrm{~m}$ on the flux tower. Scales on the $y$-axis differ in each panel. Unit of GPP $\mathrm{dd}_{\mathrm{d}}$ and TER $\mathrm{dd}$ is $\mathrm{gC} \mathrm{m} \mathrm{m}^{-2} \mathrm{day}^{-1}$. All the plots are in daily time resolution

uptake is also reflected in the low LAI values in this season [20].

This situation changes in the pre-monsoon when the $T_{\mathrm{a}}$ [19] precip $_{\mathrm{mm}}$ (Fig. 2a) and PPFD dd $_{\text {(Fig. 2b) all record }}$ increasing trends. This warmer and wetter condition with aplenty radiation renders the environment suitable for the photosynthesis and plant growth. It is reflected in $\mathrm{NEE}_{\mathrm{dd}}$ that remains mostly negative during this season (Fig. 3). This photosynthetic uptake of carbon by the ecosystem results in a sharp increase of $\mathrm{GPP}_{\mathrm{dd}}$ in this season (Fig. 4), also supported by the increasing LAl in this season [20]. However, such high growth of plants also results in the increased plant growth respiration. Additionally, the increased rainfall during this season increases the water content in the soil which subsequently results in an enhancement of the soil respiration. These two respirative fluxes together show an increasing trend in the $T_{E R}$ dd (Fig. 4). Such increase in TER in correlation with the pre-monsoon rainfall has been reported from a tropical semi-arid savannah in Botswana by Veenendaal et al. [109] where the large $\mathrm{CO}_{2}$ emission spikes after isolated rainfall events drove the ecosystem to act as net source of atmospheric $\mathrm{CO}_{2}$ in this season. Similarly, the net uptake of atmospheric $\mathrm{CO}_{2}$ by a woodland in the North American monsoon region of Arizona is reported to be less in monsoon due to the increased respiration from the available sources of carbon [97]. According to Verduzco et al. [110], the respiratory release of carbon by a tropical dry forest in Mexico is enhanced by the winter rainfall and regulates the role of this ecosystem as net source or sink of atmospheric $\mathrm{CO}_{2}$.

The biosphere-atmosphere interaction becomes more complex in the monsoon when the $\mathrm{NEE}_{\mathrm{dd}}$ is negative in the beginning of the season (June and July) but changes to be positive by the middle of the season in August. Typically in June and July, the total rainfall is high with higher cumulative monthly precipitation (Fig. 2a). The average daily $T_{\mathrm{a}}$ is almost fixed at $27^{\circ} \mathrm{C}$ in June, while it goes down gradually in July and plummets to $24^{\circ} \mathrm{C}$ by the end of this month [19].

This decreasing trend in $T_{\mathrm{a}}$ arises due to the drop in $R_{\mathrm{g}}$ observed during this period (Fig. 2b). This is due to the presence of deep and dark monsoonal convective clouds [88], which could also be seen from the satellite imagery [32], and prevents the penetration of $R_{\mathrm{g}}$ to the Earth surface. This phenomenon is also reported by Padma Kumari and Goswami [77]. Such a cloud-induced decrease in $R_{\mathrm{g}}$ brings the PPFD ${ }_{d d}$ down in this period (Fig. 2b). Quantitatively, PPFD ${ }_{\text {dd }}$ decreases almost down to $10 \mathrm{~mol} \mathrm{~m}^{-2}$ day $^{-1}$ by the end of July from $55 \mathrm{~mol} \mathrm{~m}^{-2}$ day $^{-1}$ at the beginning of June. Overall, these events have a deep impact on the GPP which declines continuously in this period.

This is in line with the studies reporting the cloudy conditions to have negative impacts on the GPP globally $[2,47]$. At KNP, such a decrease in $\mathrm{GPP}_{\text {dd }}$ results in a diminishing trend in the LAI [20]. As the plant growth is restricted, the growth respiration of plants also goes down reflecting in a decreasing trend in TER $\mathrm{dd}_{\text {(Fig. 4). }}$ (F) Overall, the KNP ecosystem continues to uptake the $\mathrm{CO}_{2}$ 
in a small quantity, approximately equal to $-2.5 \mathrm{gC} \mathrm{m}^{-2}$ day $^{-1}$, in June, but it starts sourcing, as strong as $5 \mathrm{gC}$ $\mathrm{m}^{-2}$ day $^{-1}$ by the month of July. This is again in accordance with an earlier study by Kwon et al. [52] who report the intense cloudy conditions during the South Korean monsoon drastically reduces the NEE of a deciduous forest.

The situation improves in the beginning of August with the restoration of $R_{\mathrm{g}}$ and PPFD $\mathrm{dd}$ to higher values (Fig. 2b), although decreasing trends are subsequently observed in $R_{\mathrm{g}^{\prime}}$ PPFD $\mathrm{dd}$ (Fig. 2b), and $T_{\mathrm{a}}$ in August and September [19]. The ecosystem releases $\mathrm{CO}_{2}$ rather than uptake during these 2 months (Fig. 3), showing $\mathrm{NEE}_{\mathrm{dd}}$ to remain mostly positive. An ample amount of rainfall during the monsoon increases the water content in the soil and subsequently makes it conducive to the decomposition of soil organic matter through microbial activities $[18,67]$. Additionally, the wet soil is porous having less $\mathrm{CO}_{2}$-holding capacity than the dry soil $[5,39,102]$. Hence, the soil releases a lot of $\mathrm{CO}_{2}$ into the atmosphere. As a combined effect of these two reasons, soil- $\mathrm{CO}_{2}$ emission increases during August and September. This accelerates the increase in $\mathrm{TER}_{\mathrm{dd}}$ during these 2 months.

The increased rainfall at KNP during the monsoon, i.e. the months of June, July, August, and September thus has the following two impacts on the carbon cycle of this ecosystem. First, during June and July rainfall has an increasing trend at KNP with annual maximum rainfall in July (Fig. 2a). During this period, the cloud cover at KNP gradually increases which hinders the penetration of incoming shortwave radiation $\left(R_{\mathrm{g}}\right)$ and photosynthetic photon flux density (PPFD) to the canopy (Fig. 2b). As a result, both GPP and TER decrease (Fig. 4). Further this inhibition of plant growth is also supported by a decreasing LAI during this period [20]. The NEE continues to be negative from pre-monsoon, but its strength gradually reduces, i.e. the measured values become less negative.

Second, during the latter part of the monsoon season (August and September) rainfall gradually decreases at KNP (Fig. 2a) and simultaneously clouds recede from the landmass improving the penetration of $R_{\mathrm{g}}$ and PPFD to the canopy at KNP (Fig. 2b), resulting in more growth of the plants reflected as increments in GPP and TER (Fig. 4). However, the NEE remains mostly positive driven by the emission from the flooded forest floor.

Finally, in the months of post-monsoon, i.e. October and November the ecosystem continues to source $\mathrm{CO}_{2}$ into the atmosphere as evident from the positive $\mathrm{NEE}_{\mathrm{dd}}$ (Fig. 3). This is due to the simultaneous decreasing trends in $T_{a^{\prime}}$ [19], precip $_{\mathrm{mm}}$ (Fig. 2a), $R_{\mathrm{g}}$ and PPFD dd $_{\text {(Fig. 2b) as observed }}$ during the withdrawal of ISM from the Indian landmass which hinders the photosynthetic uptake as well as the respiration (Fig. 4).
The monthly total values of NEE, GPP and TER (NEE ${ }_{m m}$ $\mathrm{GPP}_{\mathrm{mm}}$ and $\mathrm{TER}_{\mathrm{mm}}$, respectively, in $\mathrm{gC}^{-2}$ ) at KNP during 2016 are listed in Table 2 . The annual values of GPP, NEE, and TER for 2016 are $2604.88 \pm 179.43,207.51 \pm 157.37$ and $2812.38 \pm 22.05 \mathrm{gC} \mathrm{m}^{-2}$ year $^{-1}$, respectively. A bimodal pattern of GPP is observed in this year. Although the gross uptake is quite large, the positive value of NEE renders the KNP ecosystem to be a net source of atmospheric $\mathrm{CO}_{2}$ in this year.

The carbon budget of KNP seems to also be severely affected by the riverine emission as this forest is located in the Brahmaputra river basin. As pointed out by Cole et al. [17], Tranvik et al. [108], Raymond et al. [89], and Liu and Raymond [58], soil and water are the two main components of a tropical forest ecosystem those contribute largely to its annual carbon budget. Outgassing from the inland waterbodies, such as lakes and rivers, reportedly drives the forest ecosystems as net sources of carbon $[11,13,91]$. The flux footprint of the KNP flux tower does not include the Brahmaputra river, except in monsoon and post-monsoon when the water level of the Brahmaputra river rises due to the heavy amount of rainfall received in the pre-monsoon and monsoon seasons and inundates the area adjoining the tower within the flux footprint. Hence, around these times the river contribution and associated processes get detected by the tower instrumentation. Such flooding of the KNP forest floor is well documented in the literature [33]. In addition to the elevated freshwater emission, it may also play a crucial role in decomposing the organic matters that contribute positively to the atmosphere-forest mutual $\mathrm{CO}_{2}$ exchange $[8,66]$.

Table 2 Monthly total NEE (NEE $\left.\mathrm{mm}_{\mathrm{m}}\right)$, GPP $\left(\mathrm{GPP}_{\mathrm{mm}}\right)$, and TER $\left(\mathrm{TER}_{\mathrm{mm}}\right)$ at KNP during 2016

\begin{tabular}{lccl}
\hline Month & $\left.\mathrm{NEE}_{\mathrm{mm}}(\mathrm{gC} \mathrm{m})^{-2}\right)$ & $\mathrm{GPP}_{\mathrm{mm}}\left(\mathrm{gC} \mathrm{m}^{-2}\right)$ & $\mathrm{TER}_{\mathrm{mm}}\left(\mathrm{gC} \mathrm{m}^{-2}\right)$ \\
\hline January & -3.71 & 112.94 & 109.22 \\
February & 46.61 & 68.90 & 115.51 \\
March & 26.77 & 188.98 & 215.75 \\
April & -7.77 & 270.93 & 263.15 \\
May & -7.09 & 366.9 & 359.82 \\
June & -13.95 & 322.73 & 308.78 \\
July & -5.21 & 219.71 & 214.50 \\
August & 41.33 & 214.82 & 256.15 \\
September & 27.77 & 299.08 & 326.85 \\
October & 32.70 & 254.03 & 286.74 \\
November & 40.56 & 182.65 & 223.20 \\
December & 29.50 & 103.21 & 132.71 \\
\hline
\end{tabular}




\subsection{Diurnal variation of NEE}

In order to compare the different strengths of $\mathrm{CO}_{2}$ uptake and release by the KNP ecosystem during the different times of day in the different seasons, the seasonal mean diurnal variations of NEE have been calculated from the gap-filled values (Fig. 5). During all the seasons, the NEE has similar diurnal variation with the negative values during the daytime resulting from the photosynthesis taking place in the presence of solar radiation and the positive values during nighttime as a sole effect of the respiration. This is even more evident from the fact that the nighttime NEE does not almost change with the time as the respiration is not directly controlled by the availability of solar radiation. However, the NEE has a prominent variation during daytime which exhibits the growth and decay of photosynthesis with the availability of light as the day progresses.

Although the different seasons have similar diurnal pattern of NEE qualitatively, the magnitudes of daytime and nighttime NEE vary widely among the seasons depending on the different stages of canopy growth, meteorology, timings of sunrise and sunset, etc. Additionally, in different seasons the maximum and minimum values of NEE and the transition between positive and negative values happen at different times of the day. At these transition points, $\mathrm{NEE}$ is zero that signifies no exchange of $\mathrm{CO}_{2}$ between the ecosystem and the atmosphere.

The maximum ecosystem uptakes (negative most NEE) during the pre-monsoon, monsoon, and postmonsoon occur around $1100 \mathrm{LT}$ and are equal to -15 , -13 , and $-14 \mu \mathrm{mol} \mathrm{m} \mathrm{m}^{-2} \mathrm{~s}^{-1}$, respectively. In all these seasons, nighttime sourcing is comparable and equal to

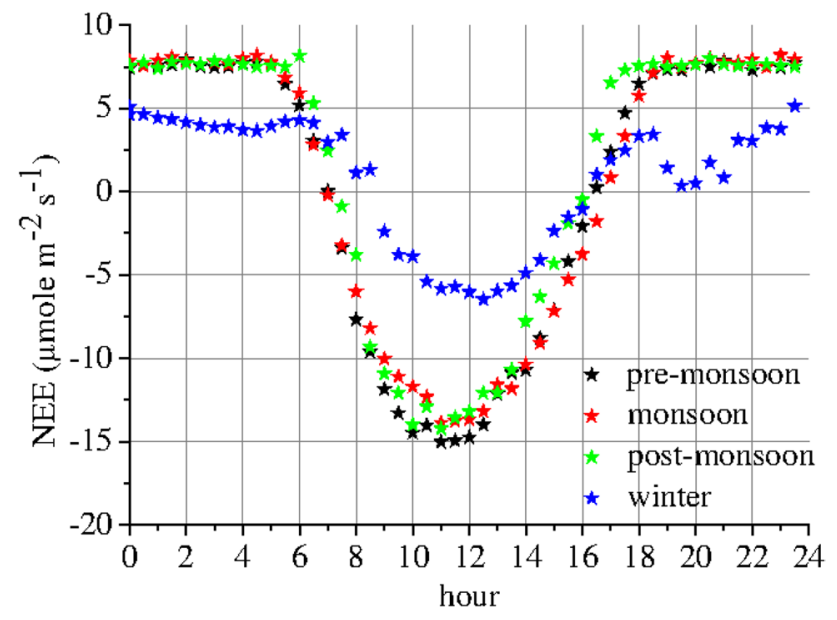

Fig. 5 Seasonal mean diurnal variations of net ecosystem exchange (NEE) at KNP during 2016. Data are from the eddy covariance (EC) system at $37 \mathrm{~m}$ on the flux tower. Time in the $\mathrm{x}$-axis is given in LT. This plot is in half-hourly time resolution
$7.5 \mu \mathrm{mol} \mathrm{m} \mathrm{m}^{-2} \mathrm{~s}^{-1}$. However, the winter is markedly different from these three seasons. The maximum sourcing and uptake observed in winter is $5 \mu \mathrm{mol} \mathrm{m} \mathrm{m}^{-2} \mathrm{~s}^{-1}$ and $-6 \mu \mathrm{mol} \mathrm{m} \mathrm{m}^{-2} \mathrm{~s}^{-1}$, respectively. Thus, the KNP ecosystem acts as a source with one-third capacity in the winter compared to the other seasons. Also the peak uptake by this ecosystem reduces by half in the winter compared to the other seasons. Additionally, the peak uptake takes place around $1300 \mathrm{LT}$ in the winter which is almost delayed by $2 \mathrm{~h}$ compared to the other times of the year. A finer scale information is available in Fig. 6 of Sarma et al. [96] that shows the mean monthly diurnal variation of NEE in this ecosystem.

Unlike other seasons of the year, NEE is not constant at nighttime during winter. Maximum NEE observed is $5 \mu \mathrm{mol} \mathrm{m} \mathrm{m}^{-2} \mathrm{~s}^{-1}$ which is much less than pre-monsoon, monsoon, and post-monsoon. It varies significantly till 0600 LT but remains positive. NEE decreases further and becomes minimum at $-6 \mathrm{~mol} \mathrm{~m}^{-2} \mathrm{~s}^{-1}$ at 1230 LT. Farther ahead in time, NEE increases up to $2.5 \mu \mathrm{mol} \mathrm{m}^{-2} \mathrm{~s}^{-1}$ at 1800 LT and dips again to zero at 2000 LT during night. Afterwards, an increasing trend is observed in NEE restoring its value to $5 \mu \mathrm{mol} \mathrm{m}{ }^{-2} \mathrm{~s}^{-1}$ at $2400 \mathrm{LT}$. Above observations can be explained as follows. Boundary layer height $(h)$ has a strong diurnal variation. After sunset, solar heating of the Earth surface stops resulting in decreased turbulence in the boundary layer. Large convective eddies are arrested resulting in the gradual decrease of $h$. As the boundary layer become stably stratified, atmospheric $\mathrm{CO}_{2}$ sinks and gets trapped within the surface layer. This is recorded as downward flux by the eddy covariance flux measurement system. Hence, a dip in the value of NEE is observed around 2000 IST in winter. However, as the night progresses the mechanical generation of turbulence takes place in the presence of the wind shear. This results in enhanced mixing at the surface layer. As a result, $h$ increases too which is recorded by the eddy covariance flux measurement system as upward flux. Hence, the magnitude of NEE increases. Around the time of sunrise, ground starts heating up due to the increasing amount of $R_{\mathrm{g}}$. This gives rise to large thermal eddies in the surface layer of the atmosphere. As a result, $h$ starts increasing and the trapped $\mathrm{CO}_{2}$ within surface layer due to the nocturnal temperature inversion is flushed upwards by these large eddies. Hence, an increase in the magnitude of NEE is observed around this time at 0600 IST. These turbulence-related effects are not observed during the other three seasons as the respirative $\mathrm{CO}_{2}$ flux dominates over the turbulence induced effects during these seasons.

The radiation and water are the two major drivers of the photosynthesis which subsequently shape the ecosystematmosphere carbon exchange. In the following sections, we study the seasonal dependencies of NEE and GPP 
on radiation and water in order to probe their seasonal variations.

\subsection{Radiation control of NEE in different seasons}

We have plotted the light response curves during the different seasons (Fig. 6) using the daytime half-hourly values of NEE, PPFD, and TER [85] and fit the Michaelis-Menten relation. Daytime is defined as the time of the day when $R_{\mathrm{g}} \geq 20 \mathrm{~W} \mathrm{~m}^{-2}$ [90]. Goodness of these fits is given by the coefficient of determination $\left(R^{2}\right)$. Estimated $a, \mathrm{NEE}_{\mathrm{sat}}, \mathrm{F}_{\mathrm{m}}$ $\mathrm{LCP}, R_{\mathrm{d}}$, and $R^{2}$ for different seasons have been summarized in Table 3.

Throughout the year, the instantaneous maximum and minimum PPFD are 2250 and $1500 \mu \mathrm{mol} \mathrm{m}^{-2} \mathrm{~s}^{-1}$, respectively, recorded in the monsoon and winter, correspondingly. The maximum (absolute value) $a$ is $-0.05 \mu \mathrm{mol} \mathrm{CO}$ $\mathrm{umol}^{-1}$ photons during the pre-monsoon and monsoon, and the minimum $a$ is $-0.02 \mu \mathrm{mol} \mathrm{CO}_{2} \mu \mathrm{mol}^{-1}$ photons

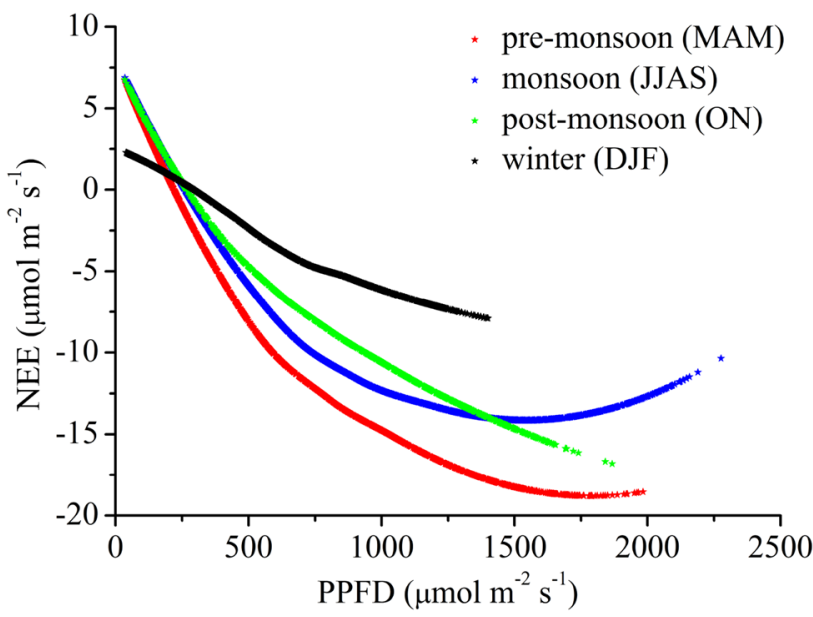

Fig. 6 Light response curves of the ecosystem at KNP during different seasons in 2016, as obtained by fitting the Michaelis-Menten relationship fit (Eq. 2) to the scatter plot between net ecosystem exchange (NEE) and photosynthetic photon flux density (PPFD) (not shown here) at half-hourly resolution. Regression coefficients for each of these fits are given in Table 1. Data are from the eddy covariance $(E C)$ system at $37 \mathrm{~m}$ and quantum sensor at $19 \mathrm{~m}$ on the flux tower in the winter. It shows that the increase in photosynthesis with available radiation is fastest in the pre-monsoon and monsoon and slowest in the winter. The $\mathrm{NEE}_{\text {sat }}$, which also represents the theoretical maximum $\mathrm{CO}_{2}$ uptake by the canopy, is maximum and minimum (absolute values) in the pre-monsoon and monsoon at -47.48 and $-35.33 \mu \mathrm{mol} \mathrm{m} \mathrm{m}^{-2} \mathrm{~s}^{-1}$, respectively. The NEE saturates in the pre-monsoon when PPFD exceeds $1800 \mu \mathrm{mol} \mathrm{m}^{-2} \mathrm{~s}^{-1}$ (Fig. 6). However, there is no such saturation in the postmonsoon and winter (Fig. 6). On the contrary, during the monsoon the NEE decreases when the PPFD exceeds beyond $1800 \mu \mathrm{mol} \mathrm{m} \mathrm{m}^{-2} \mathrm{~s}^{-1}$ (Fig. 6). Such a depression of NEE at the higher values of PPFD is reported for different natural ecosystems $[48,122]$.

According to Fig. 6, although the required radiation for photosynthesis is maximum in the monsoon the premonsoon is the most preferred season for photosynthesis by the KNP ecosystem as evident from the increasing trend in GPP observed in the pre-monsoon (Fig. 4). The fact that despite providing the maximum radiation monsoon is not the most preferred season for photosynthesis is understandable as it is also the hottest season at KNP [19] and the capacity of photosynthesis of an ecosystem falls drastically on the hotter days [49]. Clearly, the winter is the least favourable of photosynthesis among all the four seasons which is also supported by the least GPP in this season (Fig. 4). The LCP remains unchanged at $250 \mu \mathrm{mol} \mathrm{m}^{-2} \mathrm{~s}^{-1}$ in all the seasons. The $R_{\mathrm{d}}$ is maximum in the monsoon and post-monsoon at $10 \mu \mathrm{mol} \mathrm{m} \mathrm{m}^{-2} \mathrm{~s}^{-1}$ which is supportive of the high TER in these two seasons (Fig. 4). Additionally, the value of $R_{\mathrm{d}}$ as predicted by Eq. 1 matches exactly with the observed TER at nighttime during the pre-monsoon, monsoon, and post-monsoon. The minimum value of $R_{\mathrm{d}}$ among all the seasons is $2.5 \mu \mathrm{mol} \mathrm{m} \mathrm{m}^{-2}$, which is observed in the winter and indicative of the low TER recorded in this season (Fig. 4).

According to Kirschbaum and Farquhar [49], the lower $F_{m}$ in the monsoon season (Table 3 ) can be attributed to the increase in the non-photorespiratory respiration by the plants on the hotter days such as in monsoon [19] which is reflected in the smaller daytime maximum uptake in the monsoon compared to the pre-monsoon

Table 3 Parameters of the Michaelis-Menten relationship fit (2) to the scatter plots between NEE and PPFD at KNP during the different seasons in 2016

\begin{tabular}{lllllll}
\hline Season & Months & $\begin{array}{l}a(\mu \mathrm{mol} \\
\mathrm{CO}_{2} \mu \mathrm{mol}^{-1} \\
\text { photons })\end{array}$ & $\begin{array}{l}\mathrm{NEE}_{\mathrm{sat}} \\
\left(\mu \mathrm{mol} \mathrm{m} \mathrm{m}^{-2}\right. \\
\left.\mathrm{s}^{-1}\right)\end{array}$ & $\begin{array}{l}F_{\mathrm{m}}\left(\mu \mathrm{mol} \mathrm{m}^{-2}\right. \\
\left.\mathrm{s}^{-1}\right)\end{array}$ & $\begin{array}{l}\mathrm{LCP} \\
\left(\mu \mathrm{mol} \mathrm{m}^{-2}\right. \\
\left.\mathrm{s}^{-1}\right)\end{array}$ & $\begin{array}{l}R_{\mathrm{d}}\left(\mu \mathrm{mol} \mathrm{m}^{-2}\right. \\
\left.\mathrm{s}^{-1}\right)\end{array}$ \\
\hline Pre-monsoon & March, April, May & -0.05 & -47.48 & -20 & 250 & 7.5 \\
Monsoon & June, July, August, September & -0.05 & -35.33 & -15 & 250 & 10 \\
Post-monsoon & October, November & -0.04 & -41.31 & -20 & 250 & 0.76 \\
Winter & December, January, February & -0.02 & -41.23 & -10 & 250 & 0.68 \\
\hline
\end{tabular}


and post-monsoon (Fig. 5). This can also happen due to the stomatal closure that takes place during the middle of the day to reduce the water loss by the plants and simultaneously brings the $\mathrm{CO}_{2}$ capture by the plants down [103]. Midday stomatal closure is also reported to happen during the well-watered (or no water-stress) conditions [104]. Similar observations have been reported earlier over different plant canopies $[48,87]$.

The Michaelis-Menten relationship could predict the relationship between NEE and PPFD well except in the winter $\left(R^{2}<0.5\right)$ when the LRC is more linear than rectangular hyperbolic. It can be explained as follows. The NEE has more linear dependence on the absorbed PPFD than the incident PPFD [93]. As the quantum sensor is installed at $24 \mathrm{~m}$ at KNP whereas the average canopy height is $20 \mathrm{~m}$, the sensor measures the incident PPFD. The LAI is lowest in this ecosystem in the winter [20] implying the annually minimum leaf coverage and subsequently reduced reflection and scattering of the incident PPFD by the vegetation canopy. Hence, a larger fraction of the incident PPFD penetrates to the bottom of vegetation canopy and gets absorbed. Thus, the measured PPFD does not differ much from the incident PPFD and makes the relation between NEE and PPFD more linear.

The widespread of data points around the LRCs in all the seasons highlights the effect of other environmental variables on the carbon exchange process between the KNP ecosystem and the atmosphere. For further insight, we investigate the link between the carbon and water cycles as both are tightly coupled to each other.

\subsection{Water use efficiency in different seasons}

The relation between $\mathrm{GPP}_{\mathrm{dd}}$ and $\mathrm{ET}_{\mathrm{dd}}$ during different seasons is plotted in Fig. 7. Additionally, to quantify the rates of increase of GPP dd with $\mathrm{ET}_{\text {dd }}$ linear relationships [120] have been fit to the scatter plots, and the fit parameters are summarised in Table 4. This table also lists the $R^{2}$ values of the fits in different seasons.

In the pre-monsoon, monsoon, and post-monsoon, the $\mathrm{GPP}_{\mathrm{dd}}$ increases linearly with the $\mathrm{ET}_{\mathrm{dd}}$ (Fig. 7), as reported globally for the several forest ecosystems [9,
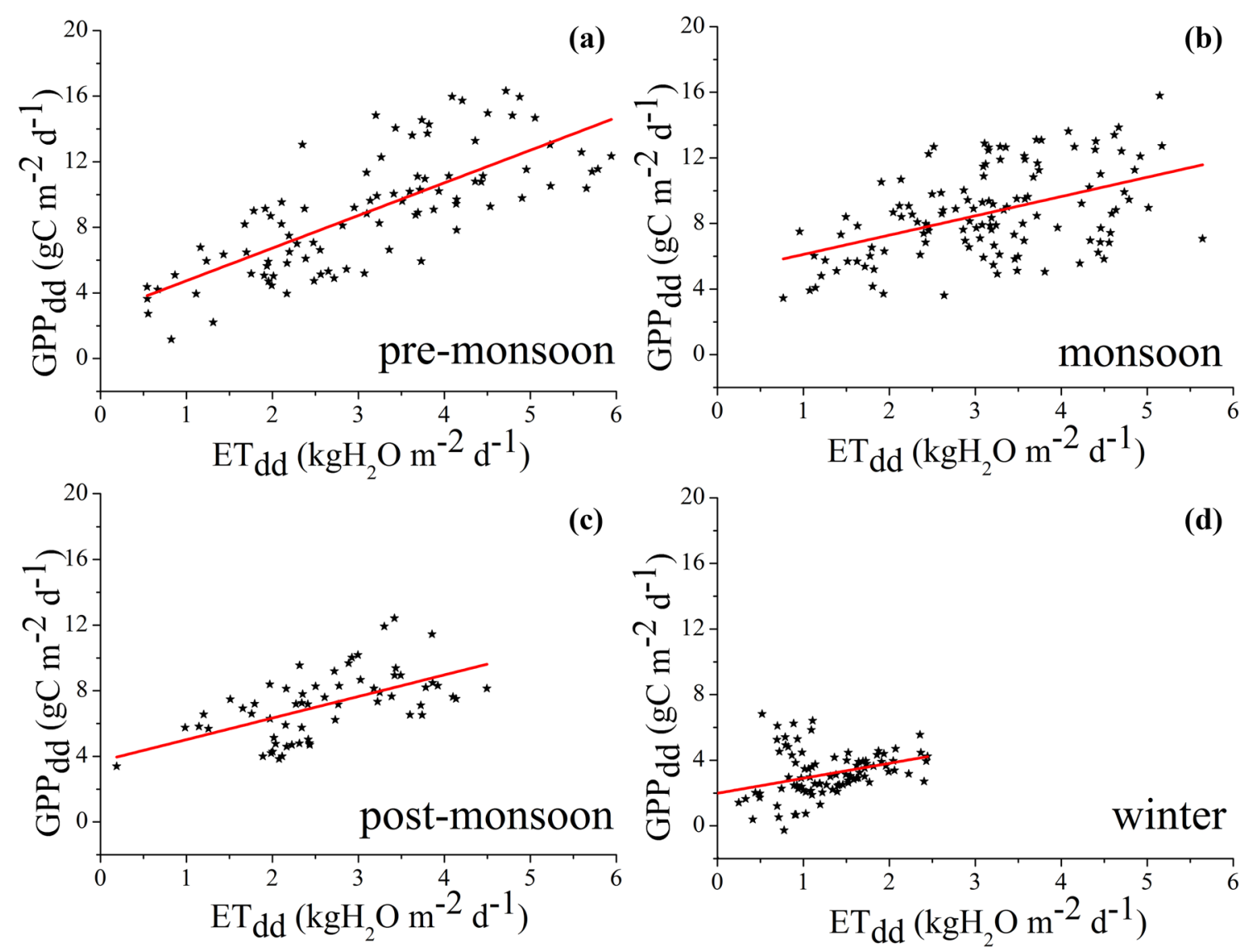

Fig. 7 Scatter plots between daily gross primary productivity $\left(\mathrm{GPP}_{\mathrm{dd}}\right)$ and daily evapotranspiration ( $\left.\mathrm{ET}_{\mathrm{dd}}\right)$ at KNP during different seasons in 2016. The red lines are linear fit to the data in different

seasons. Fit parameters and goodness of fit are given in Table 3. Data are from the eddy covariance $(\mathrm{EC})$ system at $37 \mathrm{~m}$ on the flux tower 
Table 4 Parameters of the linear fit to the scatter plots between $\mathrm{GPP}_{\mathrm{dd}}$ and $\mathrm{ET}_{\mathrm{dd}}$ at KNP during different seasons in 2016

\begin{tabular}{llll}
\hline Season & $\begin{array}{l}\text { slope }(\mathrm{gC} \\
\left.\mathrm{kg}^{-1} \mathrm{H}_{2} \mathrm{O}\right)\end{array}$ & $\begin{array}{l}\text { intercept }\left(\mathrm{gC} \mathrm{m}^{-2}\right. \\
\left.\text { day }^{-1}\right)\end{array}$ & $R^{2}$ \\
\hline Pre-monsoon & 2.00 & 2.76 & 0.56 \\
Monsoon & 1.12 & 4.94 & 0.22 \\
Post-monsoon & 1.31 & 3.70 & 0.31 \\
Winter & 0.91 & 1.99 & 0.10 \\
\hline
\end{tabular}

$10,99,100,107,118]$. However, the slope or $\mathrm{WUE}_{\mathrm{dd}}$ is maximum at $2.00 \mathrm{gC} \mathrm{kg}^{-1} \mathrm{H}_{2} \mathrm{O}$ in the pre-monsoon and minimum at $0.91 \mathrm{gC} \mathrm{kg}^{-1} \mathrm{H}_{2} \mathrm{O}$ in the winter. The annual maximum value of $\mathrm{ET}_{\mathrm{dd}}$ is $6 \mathrm{kgH}_{2} \mathrm{O} \mathrm{m}^{-2}$ day $^{-1}$, observed in the pre-monsoon and monsoon (Fig. 7), showing the evapotranspirative water loss by the KNP ecosystem is maximum in these two seasons. Additionally, the annual maximum value of GPP $\mathrm{dd}_{\mathrm{d}}$ is $16 \mathrm{gC} \mathrm{m}^{-2}$ day $^{-1}$, also observed in these two seasons. This is supportive of the photosynthesis being much more robust in these two seasons as explained in Sect. 3.3.

Compared to the pre-monsoon, the $\mathrm{WUE}_{\mathrm{dd}}$ is smaller in the monsoon at $1.12 \mathrm{gC} \mathrm{kg}^{-1} \mathrm{H}_{2} \mathrm{O}$ (Fig. $7 \mathrm{~b}$ ), showing that the photosynthesis and ET are less tightly coupled in this season compared to the pre-monsoon. There can be two possible explanations behind this. Firstly, it can happen due to a hindrance to the photosynthesis due to an early stomatal closure in the monsoon. Secondly, as the ET is composed of the evaporation and transpiration an increase in the evaporation during the monsoon will enhance the $\mathrm{ET}_{\mathrm{dd}}$, but will have no effect on the GPP $\mathrm{dd}_{\mathrm{d}}$ as the evaporation and photosynthesis are two uncoupled processes. The increased role of evaporation in this season is also supported by the more scatter in the GPP dd versus $\mathrm{ET}_{\text {dd }}$ plot (Fig. 7b) which brings the $R^{2}$ value down to 0.22 during this season.

In the winter, the mutual dependence between GPP ${ }_{d d}$ and $\mathrm{ET}_{\mathrm{dd}}$ is not as systematic as in the three other seasons; although a weak increasing trend is visible, the data points are more randomly distributed (Fig. $7 \mathrm{~d}$ ). The maximum $\mathrm{ET}_{\mathrm{dd}}$ in the winter is merely $2.5 \mathrm{kgH}_{2} \mathrm{O} \mathrm{m}^{-2}$ day $^{-1}$, minimum among all the seasons rendering the winter to be the driest season. Moreover, the maximum $\mathrm{GPP}_{\mathrm{dd}}$ is close to $7 \mathrm{gC} \mathrm{m}^{-2}$ day $^{-1}$, which is much less compared to the pre-monsoon and monsoon. This observation strengthens the hypothesis that the winter is the least favoured season by the KNP ecosystem for photosynthesis, as explained in Sect. 3.5. Subsequently, a reduced photosynthesis hinders the transpiration. Additionally being a dry season [19], the evaporation is also less during the winter. Combined together, it would mean a loosely coupled relationship between the GPP and ET which is verified by the annual minimum $W E_{d d}$ of $0.91 \mathrm{gC} \mathrm{kg}^{-1} \mathrm{H}_{2} \mathrm{O}$ in this season (Table 4).

\section{Discussions}

Our study emphasizes that an increased respiration is the possible explanation behind the KNP ecosystem acting as a net source of atmospheric $\mathrm{CO}_{2}$ in 2016. This is supportive of the several recent studies reporting the multiple tropical forest ecosystems to act as net sources of atmospheric $\mathrm{CO}_{2}$ in this year $[57,68]$. Against the long-standing belief in the scientific community that the tropical forests act as a large sink of carbon $[64,79]$, a recent study by Baccini et al. [4] shows that the forests in tropical Asia, Africa and America may be a net source of carbon based on bottom-up measurements. Their study also points out that top-down estimates from the satellites data predict the opposite phenomena, and therefore, a large uncertainty persists in the carbon budget of the tropical forest which remains inconclusive so far. Additionally, in several other studies multiple forest ecosystems were reported to act as a net atmospheric $\mathrm{CO}_{2}$ source $[60,75,76]$.

In addition to the tall trees, the understory vegetation at KNP mainly comprises the grasslands. As shown by Dubbert et al. [24], the understory grassland can contribute up to $51 \%$ of the total NEE of an ecosystem. Based on two-level separate EC measurements for overstory and understory vegetation, $\mathrm{Ma}$ et al. [61] show the overstory vegetation to act as a net sink of the atmospheric carbon, whereas the understory acts as a persistent carbon source and thus reduces the total carbon uptake of a savannah. Similar findings are reported by Jarosz et al. [43] for a Pine plantation with grass understory. However, the effect of grassland understory on the carbon cycle of the KNP ecosystem cannot be separately quantified from our one-level EC measurement.

The daily GPP of the KNP ecosystem has been calculated earlier by Deb Burman et al. [20] during a 1-yearlong period from July 2015 to June 2016 using the in situ meteorological measurements and LAl; no EC flux measurement was used. According to this study, the annual GPP of the KNP ecosystem is $2110 \mathrm{gC} \mathrm{m}^{-2}$ year $^{-1}$, which reasonably matches our estimate of $2604.88 \mathrm{gC} \mathrm{m}^{-2}$ year $^{-1}$ for 2016. However, in the present study peaks are observed in GPP by the middle and end of monsoon, in the months of August and September in 2016, respectively. These peaks in GPP coexist with the simultaneous peaks in TER and probably result from the increased soil $\mathrm{CO}_{2}$ emission triggered by the increased soil water content driven by the Indian summer monsoon rainfall. Due to these increments in TER, NEE also records two positive peaks around the same times. Thus, the soil $\mathrm{CO}_{2}$ release to the atmosphere 
renders the KNP ecosystem to be a net source around these times. This mechanism is completely uncorrelated with the photosynthetic uptake and hence the GPP and subsequent growth of the vegetation canopy. The flux partitioning method applied in our case works in 30-min time steps, which as pointed out by Reichstein et al. [90] is better suited to capture the variation in TER more accurately in short time durations following the temperaturedependent Lloyd-Taylor model. This in turn results in more precise estimates of the carbon cycle components in seasonal or annual scales. Additionally, the understory growth of grassland at KNP may contribute significantly to the annual $\mathrm{CO}_{2}$ exchange.

Although several earlier studies exist in India reporting $\mathrm{CO}_{2}$ and water vapour fluxes from different ecosystems, the annual components of the carbon cycle are reported in very few of those and the role of Indian summer monsoon on the carbon cycle remains unresolved. Over a mangrove forest in the Bay of Bengal coast of east India $\left(21^{\circ} 49^{\prime} \mathrm{N}, 88^{\circ} 37^{\prime} \mathrm{E}\right)$, the annual NEE, GPP, and TER are reported to be $-249 \pm 20,1271$ and $1022 \mathrm{gC} \mathrm{m}^{-2}$ year $^{-1}$, respectively [92]. For a moist broadleaf Sal forest in north India $\left(30^{\circ} 7^{\prime} \mathrm{N}, 78^{\circ} 13^{\prime} \mathrm{E}\right)$, the annual NEE, GPP and TER are $-507.89,2916.19$ and $2404.32 \mathrm{gC} \mathrm{m}^{-2}$ year $^{-1}$, respectively [115]. Although these ecosystems act as net sinks of carbon, these authors point out the reduction in carbon sequestration in the months with decreased radiation of the Indian summer monsoon. Such a reduction is, however, apparently absent at an evergreen coniferous forest located in the humid subtropical climate in the western Himalayan foothills where more uptake is observed during the monsoon months [72]. The annual NEE, GPP and TER of this ecosystem are $-1172,2044$ and $872 \mathrm{gC} \mathrm{m}^{-2}$ year $^{-1}$, respectively. A deciduous forest in north India has a cumulative NEE of $-860 \mathrm{gC} \mathrm{m}^{-2}$ during a 9-month-long study from January to September [113]. Patil et al. [82] report that a rural site in south India $\left(16^{\circ} 44^{\prime} \mathrm{N}, 77^{\circ} 59^{\prime} \mathrm{E}\right)$ acts as a net carbon sink during the Indian summer monsoon months in 2011. In a study over China, the annual carbon cycles of a subtropical evergreen broadleaf forest in subtropical monsoon humid climate $\left(23^{\circ} 10^{\prime} \mathrm{N}, 112^{\circ} 31^{\prime}\right.$ $\mathrm{E}$ ) and a tropical seasonal rainforest in humid subtropical climate $\left(21^{\circ} 56^{\prime} \mathrm{N}, 101^{\circ} 16^{\prime} \mathrm{E}\right)$ have been compared by Yan et al. [119]. The annual NEE of these ecosystems are $-397 \pm 93.7$ and $-166.1 \pm 49.3 \mathrm{gC} \mathrm{m}^{-2}$ year $^{-1}$, respectively, GPP are $-1384 \pm 48.6$ and $-2330.9 \pm 161.1 \mathrm{gC} \mathrm{m}^{-2}$ year $^{-1}$, respectively, and TER are $-978 \pm 48.5$ and $-2169.9 \pm 161.1$ $\mathrm{gC} \mathrm{m}^{-2}$ year $^{-1}$, correspondingly. In this study, the tropical forest is seen to act as a source of carbon during the monsoon, whereas the subtropical forest continues to sequester carbon during this period.

The dynamic global vegetation models (DGVM) used in the top-down inversion studies for allocating source, sink, and transport of $\mathrm{CO}_{2}$ over the south Asia predict the peak $\mathrm{CO}_{2}$ uptake over India during June to August. This is in contradiction with the bottom-up terrestrial ecosystem models that predict the peak $\mathrm{CO}_{2}$ uptake to take place in September and October [83, 84]. Hence, both of these approaches miss to capture the seasonality of $\mathrm{CO}_{2}$ flux over the Indian region as induced by the Indian summer monsoon. However, our surface flux measurement at KNP clearly shows the presence of both the peaks in GPP over this forest, one in the end of May and another in the end of September.

According to our analysis, the forest ecosystem at KNP acted as a net source of $\mathrm{CO}_{2}$ in 2016 which is supported by the findings of Sarma et al. [96]. However, it needs to be cross-checked against multi-year observations so that the interannual variations can be pointed out. As found out by several researchers, old forests most often offer neutral or slightly negative carbon budget due to their matured growth $[15,101]$. However, as their sinking potential is not very large it can very well be masked by the uncertainties which can render the net carbon budget as positive [22, 94]. The effect of such uncertainties can be more severe in the case of ecosystems having marginally neutral carbon budgets. Above-mentioned issues need to be seriously addressed using multi-year observations before the actual carbon sequestration potential of the KNP ecosystem is properly estimated.

\section{Conclusions}

Earlier attempts to quantify the carbon budget over south Asia have been paralysed by the limited availability of surface measurements. Serious imbalance exists between the top-down inversion models and the bottom-up terrestrial ecosystem models, both in terms of magnitude and timing of the $\mathrm{CO}_{2}$ fluxes. Our observations are helpful for fine tuning the terrestrial ecosystem models that fail to capture the seasonality of the $\mathrm{CO}_{2}$ fluxes over India as induced by the Indian summer monsoon. This will also reduce the data unavailability over India and subsequently reduce the bias in the inverse modelling predictions of sources, and sinks over this region that are mostly corrupted by the available input data from the surrounding territories. The following key findings can be summarized as the outcome of the present study:

1. The forest ecosystem at the KNP site in north-east India acts as a net source of atmospheric $\mathrm{CO}_{2}$ in 2016 with an NEE of $207.51 \pm 157.37 \mathrm{gC} \mathrm{m}^{-2}$ year $^{-1}$. In the same period, the GPP and TER of this ecosystem are $2604.88 \pm 179.43$ and $2812.38 \pm 22.05 \mathrm{gC} \mathrm{m}^{-2}$ year $^{-1}$, 
respectively. These need to be validated against the multi-year measurements.

2. We hypothesize that the clouds during the Indian summer monsoon months of June and July result in the less availability of photosynthetically active radiation severely reducing the photosynthetic uptake of $\mathrm{CO}_{2}$ by this forest canopy, and this effect is subsequently reflected in a bimodal annual GPP pattern for 2016.

3. Both the daytime uptake and nighttime release of $\mathrm{CO}_{2}$ by this canopy are maximum in the pre-monsoon, monsoon and post-monsoon and minimum in the winter.

4. The pre-monsoon and winter are the most and least favoured seasons for the photosynthetic $\mathrm{CO}_{2}$ uptake by this forest canopy.

5. The photosynthesis and evapotranspiration are most and least strongly coupled in the pre-monsoon and winter, respectively.

Acknowledgements The authors extend their sincere gratitude to the Director, Indian Institute of Tropical Meteorology (IITM), Pune, for his constant support and encouragement. We acknowledge the contributions of all the members of the MetFlux India team for establishing and maintaining the flux tower sites. The IITM is supported by the Ministry of Earth Sciences (MoES), the Government of India, New Delhi. We thank the National Data Centre, IMD Pune, for providing the long-term rainfall measurement at Tezpur. The data used in this study are provided as supplementary material 2 .

\section{Compliance with ethical standards}

Conflict of interest On behalf of all authors, the corresponding author states that there is no conflict of interest.

\section{References}

1. Ahongshangbam J, Patel NR, Kushwaha SPS et al (2016) Estimating gross primary production of a forest plantation area using eddy covariance data and satellite imagery. J Indian Soc Remote Sens 44:895-904. https://doi.org/10.1007/s1252 4-016-0564-7

2. Alton PB (2008) Reduced carbon sequestration in terrestrial ecosystems under overcast skies compared to clear skies. Agric For Meteorol 148:1641-1653. https://doi.org/10.1016/j.agrfo rmet.2008.05.014

3. Aubinet M, Vesala T, Papale D (2012) Eddy covariance: a practical guide to measurement and data analysis. Springer, Berlin

4. Baccini A, Walker W, Carvalho L et al (2017) Tropical forests are a net carbon source based on aboveground measurements of gain and loss. Science 358:230-234. https://doi.org/10.1126/ science.aam5962

5. Baldocchi DD (2008) 'Breathing' of the terrestrial biosphere: lessons learned from a global network of carbon dioxide flux measurement systems. Aust J Bot 56:1-26. https://doi. org/10.1071/BT07151

6. Barman R, Jain AK, Liang M (2014) Climate-driven uncertainties in modeling terrestrial gross primary production: a site level to global-scale analysis. Glob Chang Biol 20:1394-1411. https://doi.org/10.1111/gcb.12474

7. Batchvarova E, Gryning SE (1994) An applied model for the height of the daytime mixed layer and the entrainment zone. Bound Layer Meteorol 71:311-323. https://doi.org/10.1007/ BF00713744

8. Battin TJ, Kaplan LA, Findlay S et al (2008) Biophysical controls on organic carbon fluxes in fluvial networks. Nat Geosci 1:95-100. https://doi.org/10.1038/ngeo101

9. Beer C, Ciais P, Reichstein M et al (2009) Temporal and amongsite variability of inherent water use efficiency at the ecosystem level. Global Biogeochem Cycles 23:1-13. https://doi. org/10.1029/2008GB003233

10. Biederman JA, Scott RL, Bell TW et al (2017) $\mathrm{CO}_{2}$ exchange and evapotranspiration across dryland ecosystems of southwestern North America. Glob Chang Biol 23:4204-4221. https ://doi.org/10.1111/gcb.13686

11. Borges AV, Darchambeau F, Teodoru CR et al (2015) Globally significant greenhouse-gas emissions from African inland waters. Nat Geosci 8:637-642. https://doi.org/10.1038/ngeo2 486

12. Burba G, Anderson D (2010) A brief practical guide to eddy covariance flux measurements: principles and workflow examples for scientific and industrial applications. Li-Cor Biosciences

13. Butman D, Raymond PA (2011) Significant efflux of carbon dioxide from streams and rivers in the United States. Nat Geosci 4:839-842. https://doi.org/10.1038/ngeo1294

14. Chatterjee A, Roy A, Chakraborty S et al (2018) Biosphere atmosphere exchange of $\mathrm{CO}_{2}, \mathrm{H}_{2} \mathrm{O}$ vapour and energy during spring over a high altitude Himalayan forest at eastern India. Aerosol Air Qual Res 18:2704-2719. https://doi.org/10.4209/ aaqr.2017.12.0605

15. Chen B, Arain MA, Khomik M et al (2013) Evaluating the impacts of climate variability and disturbance regimes on the historic carbon budget of a forest landscape. Agric For Meteorol 180:265-280. https://doi.org/10.1016/j.agrformet.2013.06.002

16. Cleverly J, Eamus D, Luo Q, Restrepo Coupe N, Kljun N, Ma X, Ewenz C, Li L, Yu Q, Huete A (2016) The importance of interacting climate modes on Australia's contribution to global carbon cycle extremes. Sci Rep. https://doi.org/10.1038/srep23113

17. Cole JJ, Prairie YT, Caraco NF et al (2007) Plumbing the global carbon cycle: integrating inland waters into the terrestrial carbon budget. Ecosystems 10:171-184. https://doi.org/10.1007/ s10021-006-9013-8

18. Curiel Yuste J, Baldocchi DD, Gershenson A et al (2007) Microbial soil respiration and its dependency on carbon inputs, soil temperature and moisture. Glob Chang Biol 13:2018-2035. https://doi.org/10.1111/j.1365-2486.2007.01415.x

19. Deb Burman PK, Sarma D, Morrison R et al (2019) Seasonal variation of evapotranspiration and its effect on the surface energy budget closure at a tropical forest over north-east India. J Earth Syst Sci 128:1-21. https://doi.org/10.1007/s12040-019-1158-x

20. Deb Burman PK, Sarma D, Williams M et al (2017) Estimating gross primary productivity of a tropical forest ecosystem over north-east India using LAI and meteorological variables. J Earth Syst Sci 126:1-16. https://doi.org/10.1007/s12040-017-0874-3

21. Deb Burman PK, Shurpali NJ, Chowdhuri S et al (2020) Eddy covariance measurements of $\mathrm{CO}_{2}$ exchange from agro-ecosystems located in subtropical (India) and boreal (Finland) climatic conditions. J Earth Syst Sci 129:1-18. https://doi.org/10.1007/ s12040-019-1305-4

22. Desai AR, Bolstad PV, Cook BD et al (2005) Comparing net ecosystem exchange of carbon dioxide between an oldgrowth and mature forest in the upper Midwest, USA. Agric For Meteorol 128:33-55. https://doi.org/10.1016/j.agrfo rmet.2004.09.005 
23. Driedonks AGM (1982) Models and observations of the growth of the atmospheric boundary layer. Bound Layer Meteorol 23:283-306. https://doi.org/10.2307/3258754

24. Dubbert M, Piayda A, Cuntz M et al (2014) Stable oxygen isotope and flux partitioning demonstrates understory of an oak savanna contributes up to half of ecosystem carbon and water exchange. Front Plant Sci 5:1-16. https://doi.org/10.3389/ fpls.2014.00530

25. Falge E, Baldocchi D, Olson R et al (2001) Gap filling strategies for defensible annual sums of net ecosystem exchange. Agric For Meteorol 107:43-69. https://doi.org/10.1016/S0168 -1923(00)00225-2

26. Falge E, Baldocchi D, Tenhunen J et al (2002) Seasonality of ecosystem respiration and gross primary production as derived from FLUXNET measurements. Agric For Meteorol 113:53-74. https://doi.org/10.1016/S0168-1923(02)00102-

27. Farquhar GD, Richards RA (1984) Isotopic composition of plant carbon correlates with water-use efficiency of wheat genotypes. Funct Plant Biol 11:539-552. https://doi.org/10.1071/ PP9840539

28. Finnigan J (2006) The storage term in eddy flux calculations. Agric For Meteorol 136:108-113. https://doi.org/10.1016/j. agrformet.2004.12.010

29. Foken T, Wichura B (1996) Tools for quality assessment of surface-based flux measurements. Agric For Meteorol 78:83-105. https://doi.org/10.1016/0168-1923(95)02248-1

30. Foken T, Göockede M, Mauder M et al (2004) Post-field data quality control. In: Lee X, Massman W, Law B (eds) Handbook of micrometeorology. Atmospheric and oceanographic sciences library, vol 29. Springer, Dordrecht

31. Gahlot S, Shu S, Jain AK, Baidya Roy S (2017) Estimating trends and variation of net biome productivity in india for 1980-2012 using a land surface model. Geophys Res Lett 44:11573-11579. https://doi.org/10.1002/2017GL075777

32. Gambheer AV, Bhat GS (2000) Life cycle characteristics of deep cloud systems over the Indian region using INSAT1B pixel data. Mon Weather Rev 128:4071-4083. https:// doi.org/10.1175/1520-0493(2000)129\%3c4071:LCCOD C\%3e2.0.CO;2

33. Ghosh S, Nandy S, Kumar AS (2016) Rapid assessment of recent flood episode in Kaziranga National Park, Assam using remotely sensed satellite data. Curr Sci 111:1450-1451

34. Gnanamoorthy P, Selvam V, Ramasubramanian R et al (2019) Diurnal and seasonal patterns of soil $\mathrm{CO}_{2}$ efflux from the Pichavaram mangroves, India. Environ Monit Assess 191:1-12. https://doi.org/10.1007/s10661-019-7407-2

35. Goswami BN (2012) South Asian monsoon. In: Lau WKM, Waliser DE (eds) Intraseasonal variability in the atmosphere-ocean climate system, 2nd edn. Springer, Berlin, pp 21-72

36. Grace J, Malhi Y, Lloyd J et al (1996) The use of eddy covariance to infer the net carbon dioxide uptake of Brazilian rain forest. Glob Chang Biol 2:209-217. https://doi. org/10.1111/j.1365-2486.1996.tb00073.x

37. Grace J, Rayment M (2000) Respiration in the balance. Nature 404:819-820. https://doi.org/10.1038/35009170

38. Guhathakurta P, Rajeevan M (2008) Trends in the rainfall pattern over India. Int J Climatol 28:1453-1469. https://doi. org/10.1002/joc.1640

39. Harper CW, Blair JM, Fay PA et al (2005) Increased rainfall variability and reduced rainfall amount decreases soil $\mathrm{CO}_{2}$ flux in a grassland ecosystem. Glob Chang Biol 11:322-334. https:// doi.org/10.1111/j.1365-2486.2005.00899.x

40. Hiller R, Zeeman MJ, Eugster W (2008) Eddy-covariance flux measurements in the complex terrain of an Alpine Valley in Switzerland. Bound Layer Meteorol 127:449-467. https://doi. org/10.1007/s10546-008-9267-0
41. Hingane LS, Rupa Kumar K, Ramana Murty BV (1985) Longterm trends of surface air temperature in india. J Climatol 5:521-528. https://doi.org/10.1002/joc.3370050505

42. Huang M, Piao S, Zeng Z et al (2016) Seasonal responses of terrestrial ecosystem water-use efficiency to climate change. Glob Chang Biol 22:2165-2177. https://doi.org/10.1111/ gcb. 13180

43. Jarosz N, Brunet $Y$, Lamaud E et al (2008) Carbon dioxide and energy flux partitioning between the understorey and the overstorey of a maritime pine forest during a year with reduced soil water availability. Agric For Meteorol 148:15081523. https://doi.org/10.1016/j.agrformet.2008.05.001

44. Jensen R, Herbst M, Friborg $T$ (2017) Direct and indirect controls of the interannual variability in atmospheric $\mathrm{CO}_{2}$ exchange of three contrasting ecosystems in Denmark. Agric For Meteorol 233:12-31. https://doi.org/10.1016/j.agrfo rmet.2016.10.023

45. Jha CS, Thumaty KC, Rodda SR et al (2013) Analysis of carbon dioxide, water vapour and energy fluxes over an Indian teak mixed deciduous forest for winter and summer months using eddy covariance technique. J Earth Syst Sci 122:1259-1268. https://doi.org/10.1007/s12040-013-0350-7

46. Kaimal JC, Finnigan JJ (1994) Atmospheric boundary layer flows: their structure and measurement. Oxford University Press, Oxford

47. Kanniah KD, Beringer J, Hutley L (2013) Exploring the link between clouds, radiation, and canopy productivity of tropical savannas. Agric For Meteorol 182-183:304-313. https://doi. org/10.1016/j.agrformet.2013.06.010

48. Kim J, Verma SB (1990) Carbon dioxide exchange in a temperate grassland ecosystem. Bound Layer Meteorol 52:135-149. https://doi.org/10.1007/BF00123181

49. Kirschbaum MUF, Farquhar GD (1984) Temperature dependence of whole-leaf photosynthesis in Eucalyptus pauciflora Sieb. Ex Spreng. Funct Plant Biol 11:519-538. https://doi. org/10.1071/PP9840519

50. Kljun N, Calanca P, Rotach MW, Schmid HP (2015) A simple twodimensional parameterisation for Flux Footprint Prediction (FFP). Geosci Model Dev 8:3695-3713. https://doi.org/10.5194/ gmd-8-3695-2015

51. Kljun N, Rotach MW, Schmid HP (2002) A three-dimensional backward Lagrangian footprint model for a wide range of boundary-layer stratifications. Bound Layer Meteorol 103:205226. https://doi.org/10.1023/A:1014556300021

52. Kwon H, Hong J, Lim J (2009) Seasonality of net ecosystem carbon exchange in two major plant functional types in Korea. Asia Pac J Atmos Sci 45:149-163

53. Law BE, Falge E, Gu L et al (2002) Environmental controls over carbon dioxide and water vapor exchange of terrestrial vegetation. Agric For Meteorol 113:97-120. https://doi.org/10.1016/ S0168-1923(02)00104-1

54. Le Quéré C, Andrew RM, Canadell JG et al (2016) Global carbon budget 2016. Earth Syst Sci Data 8:605-649. https://doi. org/10.5194/essd-8-605-2016

55. Lemon E, Wright J (1969) Photosynthesis under field conditions. XA. Assessing sources and sinks of carbon dioxide in a Corn (Zea mays L.) crop using a momentum balance approach. Agron J 61:405-411. https://doi.org/10.2134/agronj1969.00021 $962006100030022 x$

56. Lindroth A, Grelle A, More A (1998) Long-term measurements of boreal forest carbon balance. Glob Chang Biol 4:443-450. https://doi.org/10.1046/j.1365-2486.1998.00165.x

57. Liu JJ, Bowman KW, Schimel DS et al (2017) Contrasting carbon cycle responses of the tropical continents to the 2015-2016 El Niño. Science 358:1-7. https://doi.org/10.1126/science.aam56 90 
58. Liu S, Raymond PA (2018) Hydrologic controls on $\mathrm{pCO}_{2}$ and $\mathrm{CO}_{2}$ efflux in US streams and rivers. Limnol Oceanogr Lett 3:428-435. https://doi.org/10.1002/lol2.10095

59. Lloyd J, Taylor JA (1994) On the temperature dependence of soil respiration. Funct Ecol 8:315-323. https://doi. org/10.2307/2389824

60. Loescher HW, Oberbauer SF, Gholz HL, Clark DB (2003) Environmental controls on net ecosystem-level carbon exchange and productivity in a Central American tropical wet forest. Glob Chang Biol 9:396-412. https://doi.org/10.1 046/j.1365-2486.2003.00599.x

61. Ma S, Baldocchi DD, Xu L, Hehn T (2007) Inter-annual variability in carbon dioxide exchange of an oak/grass savanna and open grassland in California. Agric For Meteorol 147:157-171. https://doi.org/10.1016/j.agrformet.2007.07.008

62. Mahanta R, Sarma D, Choudhury A (2013) Heavy rainfall occurrences in northeast India. Int J Climatol 33:1456-1469. https://doi.org/10.1002/joc.3526

63. Malhi Y, Grace J (2000) Tropical forests and atmospheric carbon dioxide. Trends Ecol Evol 15:332-337. https://doi. org/10.1016/S0169-5347(00)01906-6

64. Malhi Y, Nobre AD, Grace J et al (1998) Carbon dioxide transfer over a Central Amazonian rain forest. J Geophys Res 103:31593-31612. https://doi.org/10.1029/98JD02647

65. Mauder M, Foken T (2006) Impact of post-field data processing on eddy covariance flux estimates and energy balance closure. Meteorol Z 15:597-609. https://doi. org/10.1127/0941-2948/2006/0167

66. Mayorga E, Aufdenkampe AK, Masiello CA et al (2005) Young organic matter as a source of carbon dioxide outgassing from Amazonian rivers. Nature 436:538-541. https://doi. org/10.1038/nature03880

67. Michalzik B, Kalbitz K, Park JH et al (2001) Fluxes and concentrations of dissolved organic carbon and nitrogen-a synthesis for temperate forests. Biogeochemistry 52:173-205. https ://doi.org/10.1023/A:1006441620810

68. Mitchard ETA (2018) Review: The tropical forest carbon cycle and climate change. Nature 559:2-9. https://doi.org/10.1038/ s41586-018-0300-2

69. Moncrieff JB, Massheder JM, de Bruin H, Elbers J, Friborg T, Heusinkveld B, Kabat P, Scott S, Soegaard H, Verhoef A (1997) A system to measure surface fluxes of momentum, sensible heat, water vapour and carbon dioxide. J Hydrol 188-189:589-611

70. Moncrieff J, Clement R, Finnigan J et al (2004) Averaging, detrending, and filtering of eddy covariance time series. In: Lee X, Massman W, Law B (eds) Handbook of micrometeorology. Atmospheric and oceanographic sciences library, vol 29. Springer, Dordrecht

71. Morrison R, Rowe RL, Cooper HM, McNamara NP (2019) Multiyear carbon budget of a mature commercial short rotation coppice willow plantation. GCB Bioenergy 11:895-909. https ://doi.org/10.1111/gcbb.12608

72. Mukherjee S, Sekar KC, Lohani P et al (2018) Investigation of scale interaction between rainfall and ecosystem carbon exchange of Western Himalayan Pine dominated vegetation. Biogeosci Discuss. https://doi.org/10.5194/bg-2018-299

73. Nakai T, Van Der Molen MK, Gash JHC, Kodama Y (2006) Correction of sonic anemometer angle of attack errors. Agric For Meteorol 136:19-30. https://doi.org/10.1016/j.agrfo rmet.2006.01.006

74. Nieuwstadt FTM (1981) The steady-state height and resistance laws of the nocturnal boundary layer: theory compared with Cabauw observations. Bound Layer Meteorol 20:3-17. https://doi.org/10.1007/BF00119920
75. Oechel W, Hastings S, Vourlitis G et al (1993) Recent change of Arctic tundra ecosystems from a net carbon dioxide sink to a source. Nature 361:520-523. https://doi.org/10.1038/361520a0

76. Oechel WC, Laskowski CA, Burba G et al (2014) Annual patterns and budget of $\mathrm{CO}_{2}$ flux in an Arctic tussock tundra ecosystem. J Geophys Res Biogeosci 119:323-339. https://doi. org/10.1002/2013JG002431

77. Padma Kumari B, Goswami BN (2010) Seminal role of clouds on solar dimming over the Indian monsoon region. Geophys Res Lett 37:1-5. https://doi.org/10.1029/2009GL042133

78. Pan Y, Birdsey R, Fang J et al (2011) A large and persistent carbon sink in the world's forests. Science (80-) 334:988-993. https ://doi.org/10.1126/science.1201609

79. Pan Y, Birdsey RA, Fang J et al (2011) A large and persistent carbon sink in the world's forests. Science (80-) 333:988-993. https://doi.org/10.1126/science.1201609

80. Papale D, Reichstein M, Aubinet M, Canfora E, Bernhofer C, Kutsch W, Longdoz B, Rambal S, Valentini R, Vesala T, Yakir D (2006) Towards a standardized processing of Net Ecosystem Exchange measured with eddy covariance technique: algorithms and uncertainty estimation. Biogeosciences 3(4):571-583

81. Parthasarathy B, Munot AA, Kothawale DR (1994) All-India monthly and seasonal rainfall series: 1871-1993. Theor Appl Climatol 49:217-224. https://doi.org/10.1007/BF00867461

82. Patil MN, Dharmaraj T, Waghmare RT et al (2014) Measurements of carbon dioxide and heat fluxes during monsoon-2011 season over rural site of India by eddy covariance technique. J Earth Syst Sci 123:177-185. https://doi.org/10.1007/s1204 0-013-0374-z

83. Patra PK, Canadell JG, Houghton RA et al (2013) The carbon budget of South Asia. Biogeosciences 10:513-527. https://doi. org/10.5194/bg-10-513-2013

84. Patra PK, Niwa Y, Schuck TJ et al (2011) Carbon balance of South Asia constrained by passenger aircraft $\mathrm{CO}_{2}$ measurements. Atmos Chem Phys 11:4163-4175. https://doi.org/10.5194/ acp-11-4163-2011

85. Pingintha N, Leclerc MY, Beasley JP et al (2010) Hysteresis response of daytime net ecosystem exchange during drought. Biogeosciences 7:1159-1170. https://doi.org/10.5194/ bg-7-1159-2010

86. Prajapati P, Santos EA (2017) Measurements of methane emissions from a beef cattle feedlot using the eddy covariance technique. Agric For Meteorol 232:349-358. https://doi. org/10.1016/j.agrformet.2016.09.001

87. Price DT, Black TA (1990) Effects of short-term variation in weather on diurnal canopy $\mathrm{CO}_{2}$ flux and evapotranspiration of a juvenile douglas-fir stand. Agric For Meteorol 50:139-158. https://doi.org/10.1016/0168-1923(90)90050-G

88. Rajeevan M, Rohini P, Niranjan Kumar K et al (2013) A study of vertical cloud structure of the Indian summer monsoon using CloudSat data. Clim Dyn 40:637-650. https://doi.org/10.1007/ s00382-012-1374-4

89. Raymond PA, Hartmann J, Lauerwald R et al (2013) Global carbon dioxide emissions from inland waters. Nature 503:355359. https://doi.org/10.1038/nature 12760

90. Reichstein $M$, Falge $E$, Baldocchi D et al (2005) On the separation of net ecosystem exchange into assimilation and ecosystem respiration: review and improved algorithm. Glob Chang Biol 11:1424-1439. https://doi.org/10.111 1/j.1365-2486.2005.001002.x

91. Richey JE, Melack JM, Aufdenkampe AK et al (2002) Outgassing from Amazonian rivers and wetlands as a large tropical source of atmospheric $\mathrm{CO}_{2}$. Nature 416:617-620. https://doi. org/10.1038/416617a 
92. Rodda S, Thumaty K, Jha C, Dadhwal V (2016) Seasonal variations of carbon dioxide, water vapor and energy fluxes in tropical Indian mangroves. Forests 7:1-18. https://doi.org/10.3390/f7020 035

93. Ruimy A, Jarvis PG, Baldocchi DD, Saugier B (1995) $\mathrm{CO}_{2}$ fluxes over plant canopies and solar radiation: a review. Adv Ecol Res 26:1-68. https://doi.org/10.1016/S0065-2504(08)60063-X

94. Saigusa N, Li SG, Kwon H et al (2013) Dataset of CarboEastAsia and uncertainties in the $\mathrm{CO}_{2}$ budget evaluation caused by different data processing. J For Res 18:41-48. https://doi.org/10.1007/ s10310-012-0378-6

95. Saigusa N, Yamamoto S, Murayama S et al (2002) Gross primary production and net ecosystem exchange of a cool-temperate deciduous forest estimated by the eddy covariance method. Agric For Meteorol 112:203-215. https://doi.org/10.1016/S0168 -1923(02)00082-5

96. Sarma D, Kumar Baruah K, Baruah R et al (2018) Carbon dioxide, water vapour and energy fluxes over a semi-evergreen forest in Assam, Northeast India. J Earth Syst Sci 127:94. https://doi. org/10.1007/s12040-018-0993-5

97. Scott RL, Edwards EA, Shuttleworth WJ et al (2004) Interannual and seasonal variation in fluxes of water and carbon dioxide from a riparian woodland ecosystem. Agric For Meteorol 122:65-84. https://doi.org/10.1016/j.agrformet.2003.09.001

98. Seibert P (2000) Review and intercomparison of operational methods for the determination of the mixing height. Atmos Environ 34:1001-1027. https://doi.org/10.1016/S1352-2310(99)00349 $-0$

99. Shi H, Li L, Eamus D et al (2014) Intrinsic climate dependency of ecosystem light and water-use-efficiencies across Australian biomes. Environ Res Lett 9:1-12. https://doi.org/10.1088/17489326/9/10/104002

100. Singh N, Patel NR, Bhattacharya BK et al (2014) Analyzing the dynamics and inter-linkages of carbon and water fluxes in subtropical pine (Pinus roxburghii) ecosystem. Agric For Meteorol 197:206-218. https://doi.org/10.1016/j.agrformet.2014.07.004

101. Song C, Woodcock CE (2003) A regional forest ecosystem carbon budget model: impacts of forest age structure and landuse history. Ecol Modell 164:33-47. https://doi.org/10.1016/S0304 -3800(03)00013-9

102. Sponseller RA (2007) Precipitation pulses and soil $\mathrm{CO}_{2}$ flux in a Sonoran Desert ecosystem. Glob Chang Biol 13:426-436. https ://doi.org/10.1111/j.1365-2486.2006.01307.x

103. Tenhunen JD, Lange OL, Gebel J et al (1984) Changes in photosynthetic capacity, carboxylation efficiency, and $\mathrm{CO}_{2}$ compensation point associated with midday stomatal closure and midday depression of net $\mathrm{CO}_{2}$ exchange of leaves of Quercus suber. Planta 162:193-203. https://doi.org/10.1007/BF00397440

104. Tenhunen JD, Lange OL, Jahner D (1982) The control by atmospheric factors and water stress of midday stomatal closure in Arbutus unedo growing in a natural macchia. Oecologia 55:165169. https://doi.org/10.1007/BF00384483

105. Tennekes $H$ (1973) A model for the dynamics of the inversion above a convective boundary layer. J Atmos Sci 30:558-567. https://doi.org/10.1175/1520-0469(1973)030\%3c0558:AMFTD O\%3e2.0.CO;2

106. Thomas $\mathrm{R}$, Prentice $\mathrm{IC}$, Graven $\mathrm{H}$ et al (2016) $\mathrm{CO}_{2}$ and greening observations indicate increasing light use efficiency in northern terrestrial ecosystems. Geophys Res Lett 18:14335. https://doi. org/10.1002/2016GL070710.Biosphere

107. Tong $X$, Zhang J, Meng $P$ et al (2017) Light use efficiency of a warm-temperate mixed plantation in north China. Int J Biometeorol 61:1607-1615. https://doi.org/10.1007/s00484-017-1339-8

108. Tranvik LJ, Downing JA, Cotner JB et al (2009) Lakes and reservoirs as regulators of carbon cycling and climate. Limnol Oceanogr 54:2298-2314. https://doi.org/10.4319/lo.2009.54.6_part_2.2298
109. Veenendaal EM, Kolle O, Lloyd J (2004) Seasonal variation in energy fluxes and carbon dioxide exchange for a broadleaved semi-arid savanna (Mopane woodland) in Southern Africa. Glob Chang Biol 10:318-328. https://doi.org/10.111 1/j.1365-2486.2003.00699.x

110. Verduzco VS, Garatuza-Payán J, Yépez EA et al (2015) Variations of net ecosystem production due to seasonal precipitation differences in a tropical dry forest of northwest Mexico. J Geophys Res Biogeosciences 120:2081-2094. https://doi.org/10.1002/2015J G003119

111. Vickers D, Mahrt L (1997) Quality control and flux sampling problems for tower and aircraft data. J Atmos Ocean Technol 14:512526. https://doi.org/10.1175/1520-0426(1997)014\%3c051 2:QCAFSP\%3e2.0.CO;2

112. Wang $B$, Ho $L$ (2002) Rainy season of the Asian-Pacific summer monsson. J Clim 15:386-398. https://doi.org/10.1175/15200442(2002)015\%3c0386:RSOTAP\%3e2.0.CO;2

113. Watham T, Kushwaha SP, Patel NR, Dadhwal VK (2014) Monitoring of carbon dioxide and water vapour exchange over a young mixed forest plantation using eddy covariance technique. Curr Sci 107:858-866

114. Watham T, Kushwaha SPS, Patel NR et al (2017) Ecosystem productivity and its response to environmental variable of moist Indian sal forest. Trop Ecol 58:761-768

115. Watham T, Patel NR, Kushwaha SPS et al (2017) Evaluation of remote-sensing-based models of gross primary productivity over Indian sal forest using flux tower and MODIS satellite data. Int J Remote Sens 38:5069-5090. https://doi.org/10.1080/01431 161.2017.1333653

116. Webb EK, Pearman Gl, Leuning R (1980) Correction of flux measurements for density effects due to heat and water vapour transfer. Q J Roy Meteorol Soc 106(447):85-100

117. Wutzler T, Reichstein M, Moffat AM, Migliavacca M (2018) REddyProc: post processing of (half-)hourly eddy-covariance measurements. R package version 1.1.3

118. Xie J, Zha T, Zhou C et al (2016) Seasonal variation in ecosystem water use efficiency in an urban-forest reserve affected by periodic drought. Agric For Meteorol 221:142-151. https://doi. org/10.1016/j.agrformet.2016.02.013

119. Yan J, Zhang Y, Yu G et al (2013) Seasonal and inter-annual variations in net ecosystem exchange of two old-growth forests in southern China. Agric For Meteorol 182-183:257-265. https:// doi.org/10.1016/j.agrformet.2013.03.002

120. Yu G, Song X, Wang $Q$ et al (2008) Water-use efficiency of forest ecosystems in eastern China and its relations to climatic variables. New Phytol 177:927-937. https://doi.org/10.111 1/j.1469-8137.2007.02316.x

121. Yu G, Chen Z, Piao S, Peng C, Ciais P, Wang Q, Li X, Zhu X (2014) High carbon dioxide uptake by subtropical forest ecosystems in the East Asian monsoon region. Proc Natl Acad Sci 111(13):4910-4915

122. Zhang WL, Chen SP, Chen J et al (2007) Biophysical regulations of carbon fluxes of a steppe and a cultivated cropland in semiarid Inner Mongolia. Agric For Meteorol 146:216-229. https://doi. org/10.1016/j.agrformet.2007.06.002

123. Zhou S, Yu B, Schwalm CR et al (2017) Response of water use efficiency to global environmental change based on output from terrestrial biosphere models. Glob Biogeochem Cycles 31:16391655. https://doi.org/10.1002/2017GB005733

124. Zhu X, Yu G, Wang Q et al (2014) Seasonal dynamics of water use efficiency of typical forest and grassland ecosystems in China. J For Res 19:70-76. https://doi.org/10.1007/s10310-013-0390-5

Publisher's Note Springer Nature remains neutral with regard to jurisdictional claims in published maps and institutional affiliations. 